\title{
Soil fauna and soil functions: a jigsaw puzzle
}

\section{María Jesús I. Briones*}

Departamento de Ecología y Biología Animal, Facultad de Biología, Universidad de Vigo, Vigo, Spain

\section{Edited by:}

Wilfred Otten, Abertay University, UK

\section{Reviewed by:}

Victor Satler Pylro, Federal

University of Viçosa, Brazil

Raymon Shange, Tuskegee

University, USA

*Correspondence:

María Jesús I. Briones,

Departamento de Ecología y

Biología Animal, Facultad de

Biología, Universidad de Vigo,

36310 Vigo, Spain

e-mail:mbriones@uvigo.es
Terrestrial ecologists and soil modelers have traditionally portrayed the inhabitants of soil as a black box labeled as "soil fauna" or "decomposers or detritivores" assuming that they just merely recycle the deposited dead plant material. Soil is one of the most diverse habitats on Earth and contains one of the most diverse assemblages of living organisms; however, the opacity of this world has severely limited our understanding of their functional contributions to soil processes and to ecosystem resilience. Traditional taxonomy, based on morphological and anatomical aspects, is becoming replaced by rapid processing molecular techniques (e.g., with marker gene-based approaches). However, this may be impracticable in many ecological studies and consequently, the majority of the current knowledge, still contributes little to our understanding of their role in ecosystem functioning. Over the years, different workers have produced several "functional classifications" based on the body width, feeding regime, certain behavioral and reproductive aspects and ecological niches of soil organisms. Unfortunately, the information available is severely restricted to "major" groups. A better physiological and metabolic understanding of when and how a complex community of soil organisms access nutrients, alter their environment and in turn, affect soil processes, will allow a more realistic quantitative evaluation of their ecological roles in the biogeochemical cycles. Here, I review the applicability of the available approaches, highlight future research challenges and propose a dynamic conceptual framework that could improve our ability to solve this functional puzzle.

Keywords: feeding ecology, functional classifications, resilience, soil organisms, soil processes, ecosystem functioning

\section{INTRODUCTION}

According to the United Nations, we are in a "decade of biodiversity" and one of the decisions adopted during the 10th meeting of Conference of the Parties held in Nagoya in October 2010 was the implementation of the "Strategic Plan for Biodiversity 2011-2020" (http://www.cbd.int/decision/cop/?id=12268). The rationale for the new plan is that "biological diversity underpins ecosystem functioning and the provision of ecosystem services essential for human well-being." One important reason for attracting interest in functional diversity is that there will be more chances for the society to support biodiversity conservation if there is an economical value associated to it.

Soils are multicomponent and multifunction systems which provide a series of "ecosystem goods" (biomass production) to humans, but also many "regulating services" (e.g., SOM decomposition, soil structure maintenance, nutrient cycling, etc.) which ensure ecosystem sustainability. All these functions are provided by the variety of organisms which live in the soil, i.e., they are functional outputs of biological processes (Kibblewhite et al., 2008). Scientific advances in soils research have increased significantly since the publication of a special issue in Science [Soils-The Final Frontier (Science 11 June 2004, Vol. 304, Issue 5677)] and the appearance of some key papers in Nature (e.g., Copley, 2000). However, whereas significant progress have been achieved regarding its physical and chemical characterization, its soil communities remain practically underexplored, with very low percentages of described species being available (Hawksworth and Mound, 1991; Torsvik et al., 1994; Walter and Proctor, 1999).

Until 1960 the role of soil fauna in ecosystems mainly concerned earthworms (reviewed by Huhta, 2007). In the following two decades, research on the contribution of soil organisms to soil processes revealed the disappointing result that their direct effects on soil organic matter (SOM) decomposition (via litter consumption) were negligible due to their low assimilation efficiency (less than 10\%; Petersen and Luxton, 1982). However, their indirect effects (through grazing on microbial communities) seemed to exceed, by several times, their metabolic contribution (MacFadyen, 1963). This is the result of soils being packed with microorganisms and thus, soil animals are believed to either rely on microorganisms as food or to use them as an "external rumen" to compensate for their poor enzymatic capabilities (Swift et al., 1979).

Consequently, SOM decomposition has been traditionally interpreted by considering climatic factors and chemical composition of the plant litter as the main drivers of this process at global scale, whereas the influence of soil biota has been relegated to local scale and for this reason, they are consistently excluded from global decomposition models (Wall et al., 2008). One interesting result from a large field scale experiment (Wall et al., 2008) was the suggestion that taxonomic richness, and not abundance or biomass (Cole et al., 2004), was the primarily driver of the observed responses (Wall et al., 2008). The main cause for this 
discrepancy was the organisms investigated in this study not being identified to species level, but to Order or even to higher taxonomical levels, which possibly led to a more functional diverse assemblage (Heemsbergen et al., 2004). This contrasts with the opinion of Mulder (2006) who argued that numerical abundance of each taxa is the most reliable method to describe ecosystem functioning, since it is a more "flexible" parameter in reflecting ecosystem state than average body mass. In support of this view, there are some other claims that functional importance of soil organisms does not match their numerical abundance (Anderson, 1988) and that functional complexity does not always influence soil processes (Liiri et al., 2002).

However, if we take into account that dominant species are likely to affect their habitat and resources availability and that keystone species or functional groups could determine the abundance, diversity and activities of other soil invertebrates (Lavelle, 1996), then the need for a functional classification is clear. Yet reducing the huge species diversity present in soils into a smaller number of functional groups will inevitably result in grouping "redundant" species regarding their function, with this being more likely to happen in species-rich faunal groups (Bardgett, 2002). This is also supported by the general assumption of a generalist feeding behavior being predominant amongst soil biota under field conditions (Luxton, 1972; Ponsard and Arditi, 2000; Scheu and Falca, 2000).

On the other hand, if higher diversity implies more species performing the same functions or services, perhaps the role of diversity is as a reserve of "natural insurance capital" (Folke et al., 1996; Yachi and Loreau, 1999) ready to enter in action in response to future environmental conditions/perturbations or to exotic invasions. The idea that "organisms have evolved through selection to maximize their contribution to future generations.... not to serve functions in the ecosystem" has long being coined (Andrén et al., 1995, 1999). Furthermore, some species which are "functionally redundant" for a given ecosystem process at a given time might nevertheless no longer be redundant under changed conditions; similarly, they could be initially inactive but become functionally active under a changing environment (Hodkinson and Wookey, 1999). This resembles the "stability vs. complexity theory" (McCann, 2000) which has been severely criticized because the concept "stability" is a vague term which implies that there are not redundant species, i.e., each one has a place in the ecosystem (Andrén and Balandreau, 1999) and refers to a wide range of different properties, which could change across different organization levels. According to this theory, processes that are carried out by a higher number of species are "more stable," whereas those carried out by a small number are most vulnerable to biodiversity losses (Hooper et al., 1995). In other words, increased species richness can lead to decreases in temporal variability in ecosystem properties (Pfisterer and Schmid, 2002; Pfisterer et al., 2004); in contrast, species losses in functional groups consisting of just a few species could result in habitat degradation. However, if all species differ in their contribution to soil processes, the loss of one species might not be functionally compensated and due to species interactions, species losses could also derive in unprecedented cascade effects (Freckman et al., 1997).
In view of this, it becomes clear that soil ecologists are in dire need to resolve the dilemma of which, "functional dissimilarity" (Heemsbergen et al., 2004) or "functional redundancy" (Andrén and Balandreau, 1999), is dominating in soils and which level of soil biodiversity (population, community or ecosystem level) should be estimated to underpin the biological regulation of soil processes. However, this is difficult to assess at large scales in the field due to the high percentage of species still waiting to be identified (ca. 75\% of the total figure; Decaëns et al., 2006, 2008), the huge range of expertise required (Wall et al., 2008) and the unavailability of well developed techniques for accurate taxa differentiation (Freckman et al., 1997).

Then, the next questions are whether the presence of one species belonging to a particular functional group is enough to maintain a particular soil process, or if having more than one species within that functional group will improve the rate of it, or whether having several functional groups within a particular animal group (e.g., earthworms) is more beneficial for ecosystem functioning. In other words, should we be promoting diversity of functional groups or diversity within the functional groups?

Interestingly, hierarchical models, in which certain taxa may be determining the abundance and diversity of other groups (Lavelle, 1996; Wardle and Lavelle, 1996) or modifying the environment so that another organism finds its niche ("metabiosis" sensu Waid, 1999), has also highlighted the importance of functional classifications that not only identify taxa with significant functional roles in the ecosystem, but also "redundant taxa" that could have a significant existence by acting as indicators of soil resilience, if under the eventual action of disturbance the soil community composition becomes altered (Lavelle, 1996; Fitter et al., 2005). Therefore, knowing the minimum number of functional groups and species within a functional group to ensure soil resilience should also be a research priority (Brussaard et al., 1997).

This review tries to synthesize the existing knowledge on functional approaches to classify soil organisms and to help in reducing the profuse use in the literature of various terms, which are not always clearly defined: diversity, species richness, functional diversity, feeding guild, functional response trait, functional effect trait, functional domains, spheres of influence, ecosystem/soil functioning (also related to soil quality, soil health and soil fertility), ecosystem properties, ecosystem goods, ecosystem services, etc. The overall aim is to seek for a common framework to better link the diversity of soil organisms to their function in the ecosystems that could improve predictions and policies.

\section{SPECIES RICHNESS: THE THIRD BIOTIC FRONTIER}

Soil biota includes bacteria, fungi, protozoans, nematodes, mites (Acari), collembolans (springtails), annelids (enchytraeids and earthworms) and macroarthropods (e.g., spiders, myriapoda, insects, woodlice). It also includes plant roots and their exudates attracting a variety of organisms, which either feed directly on these secretions or graze on the microorganisms concentrated near the roots and hence, receiving the name of "rhizosphere" (first coined by Hiltner, 1904; see also the review of his work by Hartmann et al., 2008). Soil biodiversity is often used as a synonym for the number of heterotrophic species below-ground 
(Hooper et al., 2005); however, taxonomic deficit increases with decreasing body size and in the case of soil biota is usually above $90 \%$ for those organisms smaller than $100 \mu \mathrm{m}$ (Decaëns, 2010). Consequently, research has been limited by their immense diversity, their small size and by technical problems. For these reasons, it has been described as the "third biotic frontier" after oceanic abysses and tropical forest canopies (André et al., 1994; Hågvar, 1998).

Species' lists provide a practical metric for assessing biological diversity and soil quality, distinguishing habitats and managing resources (Costello et al., 2013). However, trying to link species diversity with ecosystem function is often hampered by the assumption that all species are potentially equal with respect to function, when there is not mechanistic relationship between these two concepts (Bengtsson, 1998). Indeed, Heemsbergen et al. (2004) concluded that "species richness" has very little influence on soil processes and consequently, communities containing the same number of species but different species combinations have different effects on ecosystem functioning. Furthermore, according to this study, saturation in processes' rates occurred with just adding more than one species and the nature of the interspecific interactions [e.g., positive (facilitation, complementary), negative (inhibition due to competition) or neutral] play the most significant role in the direction and magnitude of their response (Heemsbergen et al., 2004; see also Hooper et al., 2005). This partly confirms previous experimental work, which showed that, for example, more nitrate was mineralized in the presence of solely one collembolan species than when more species were added (Faber and Verhoef, 1991). This can be explained in terms of species' functional attributes and thus, the greater differences in functional characteristics between species, the greater strength of the interspecific interactions (Stevens and Carson, 2001; Chesson et al., 2002). In addition, environmental factors (abiotic and biotic) could also change the strength of these interactions (e.g., Hooper and Dukes, 2004).

\section{SPECIES' FUNCTIONAL ATTRIBUTES: KEY PLAYERS IN REGULATING ECOSYSTEM FUNCTIONING}

Advances in molecular techniques have revolutionized the way we describe species. Over the last 15 years the Natural History Museum in London (UK) has seen a $12 \%$ replacement of "traditional" taxonomists with molecular biologists (Boxshall and Self, 2011). Molecular markers appear to be the promising tool in assessing the diversity of soil organisms when morphological taxonomy is unachievable and when trying to solve some nomenclature problems derived from the existence of an elevated number of synonyms and species complexes (e.g., Coomans, 2002; Briones et al., 2009; Emerson et al., 2011; Porco et al., 2013). However, at least for certain soil organisms, much work remains to be done in this field to reconcile species synonyms, which might take long time as result of the low accessibility to many species descriptions (Costello et al., 2013).

One added complication is that even the species' definition is not without problems since many soil organisms contain species that are parthenogenetic (e.g., earthworms, plant-parasitic nematodes, mites, and collembolans) or that reproduce asexually by fragmentation (e.g., some enchytraeids).
Finally, the existence of cryptic species further complicates the application of molecular markers-based approaches (Huang et al., 2007; King et al., 2008; Richard, 2008; Rougerie et al., 2009; Porco et al., 2012). For example, very recent work trying to assess the genetic diversity of the genus Cognettia (Annelida, Oligochaeta, Enchytraeidae) has revealed that the most relevant species in soil ecological studies (C. sphagnetorum) comprises at least four different lineages which can co-ocurr at the same site, and with potential physiological and ecological differences (Martinsson and Erséus, 2014). Importantly, not only the identity of this species and other species within this genus were questioned, but also the phylogenetic relationships among these species varied between the gene trees as a result of "phylogenetic errors" not corrected by the model. Therefore, despite their great potential, these modern tools are in dire need for improving their mathematical procedures to analyze the species trees and for overcoming other methodological shortcomings in relation to nucleic acids extraction procedures, standardization of the methods to allow qualitative and quantitative comparisons, sequencing error rates, missing confident databases, etc. (Chang et al., 2009).

According to Brussaard et al. (1997), the goal of molecular taxonomy is not only to link molecular data to species, rather than broad taxonomic groups, but also to performance in the field. One way of reducing this major challenge is perhaps, to concentrate our efforts in "key stone species," those species whose effects on their communities or ecosystems are larger than expected from their abundance or biomass (Power and Mills, 1995). If only a few species are more relevant than others, because their functional attributes could have a strong impact on soil processes, it becomes obvious that determining each species-specific contribution to each soil function should be a research priority. For example, the enchytraeid species $C$. sphagnetorum has been classified as one of this type in boreal coniferous forest soils, due to its relevant role in the decomposition processes in these particular systems (Laakso and Setälä, 1999). However, it has been argued that a dominant species could also act as a keystone species (Bengtsson, 1998) and indeed, in these boreal systems, C. sphagnetorum could make up more than 95\% of total enchytraeid numbers (Huhta et al., 1986). By focusing on the causal effect, "keystone-process species" (Folke et al., 1996), it would be possible to obtain a functional attribute irrespective of their number or size.

If we accept that not every species in the soil has the same importance for ecosystem functioning, we could also argue that perhaps the members of the same species might also not be identical and hence, they might not have the same function in the soil (Lavelle et al., 1997; Wolters, 2001). Therefore, identifying genotypes with functional attributes could be our next research aim if we wish to be able to manage soil biodiversity and ecosystems and to face environmental changes. Accordingly, "metagenomes" [i.e., genomic, evolutionary, and functional information recovered directly from soil samples and not from artificial systems (clonal cultivations)] represent the new era to gain new insights into the relationships between genetic and functional diversity (Torsvik and Øvreås, 2002). These new approaches have been successfully applied to microbial communities from distinct biomes (Fierer et al., 2012) and showed, for the first time, that desert communities could be linked to both higher osmoregulation and 
dormancy capabilities and to lower influences on nutrient cycling and the catabolism of plant-derived organic compounds, whereas non-desert ones seem to have more competitive skills in terms of greater antibiotic resistance. Despite the authors' acknowledgement of some methodological, spatial and temporal limitations in their conclusions, it is the most comprehensive attempt to relate functional gene diversity to large-scale geographical gradients. Since the number of species or genotypes necessary to preserve ecosystem functioning increases with increasing spatial and temporal scales (Hooper et al., 2005), the research task ahead is overwhelming, but as sequencing capacities and analyzing procedures become more effective, coupling genetic and functional diversity with environmental gradients across time and space seems plausible in the near future (Fierer et al., 2012).

\section{FUNCTIONAL GROUPS: THE IMPORTANCE OF TEAM WORK}

Although certain soil functions can be performed by one key species, it could also be hypothesized that a battery of similarly equipped players (rich taxonomical diversity but functional redundancy) could be responsible for the same soil function or at least, contribute to that particular function in some ways. Indeed, the term "functional group" was first coined by Cummins (1974) and defined as "a group of organisms which affects a process in a similar way." The concept immediately attracted scientific attention and consequently, over the years, several classifications, in which several taxa with a potential similar role in ecosystem functioning were fitted into major broad groups, have been produced.

\section{BODY SIZE}

Perhaps, the first attempt to provide a functional classification of soil organisms was using their body width as the main classificatory criterion: (i) $<100 \mu \mathrm{m}$ including microbiota (bacteria and fungi) and micro-fauna (protozoa and nematodes), (ii) $>100 \mu \mathrm{m}$ and $<2 \mathrm{~mm}$ referring to mesofauna (acari, springtails, diplura, symphylans, enchytraeids) and (iii) $>2 \mathrm{~mm}$ which includes the macrofauna (e.g., mollusc, spiders, insects, earthworms) (Wallwork, 1970; Swift et al., 1979). Unfortunately, the ranges that determine each group size are not exact for all the members of each group, often leading to considerable confusion as to whether a particular organism should be considered macro, meso or micro. Furthermore, in order to get a better understanding of the quantitative role of soil animals in ecosystems live biomass data is required (Abrahamsen, 1973), which is not always feasible. Therefore, for comparison purposes, body length (Figure 1) might represent a better parameter since a number of length-weight conversion models are available (e.g., Abrahamsen, 1973; Petersen, 1975).

Nonetheless, the size classification based on body width has been successfully applied in addressing several ecological questions (primarily their effects on SOM decomposition) and it is still in practical use today. For example, Huhta (2007) ranked the contribution of soil fauna to ecosystem functions so that macrofauna (earthworms followed by isopods and diplopods) was ranked first and mesofauna (enchytraeids) second, with the latter only having a predominant role when those larger bodied animals were less numerous or totally absent. This ranking was based on previous experimental work in which the absence of macrofauna (earthworms) significantly increased $\mathrm{N}$-uptake of pine and birch seedlings (Setälä and Huhta, 1991; Setälä, 1995, 2000). Similarly, Bradford et al. (2007) also concluded that smaller-bodied fauna do not always compensate for the absence of macrofauna in terms of regulating the dynamics of recently photosynthesized carbon.

However, a number of laboratory and field studies failed to show the pivotal role of macrofauna. Thus, Setälä et al. (1996) found that the reduction of macrofauna population numbers, through increased predation by coleopterans and centipedes, did not affect growth of poplar seedlings or the nitrogen content of their leaves, whereas the removal of soil mesofauna led to reduced nitrogen uptake by the seedlings. Similarly, despite the greater dominance of macrofauna (earthworms) in an upland organic grassland, was the mesofauna (mites and collembolans), representing only $3 \%$ of the total biomass, the group responsible for processing the majority of the recent photosynthesized carbon (Ostle et al., 2007). Finally, other laboratory studies (Schulz and Scheu, 1994; Filser, 2003) concluded that while macrofauna (earthworms, Diplopoda, Isopoda), mesofauna (enchytraeids) and bacterial feeding microfauna all enhanced SOM decomposition, other mesofaunal groups (collembolans and oribatid mites) showed highly variable results depending on the species considered and incubation conditions.

Among the smaller-sized organisms, microbiota deserves special consideration since they seem to have limitless capacities to access and digest any substrate in the soil. However, our understanding of the functional capabilities of soil microbial communities is still very limited and often focused on particular processes (e.g., $\mathrm{N}_{2}$ fixation) and requires further assessment to resolve large-scale biogeographical patterns in microbial diversity, community composition and functional attributes (Fierer et al., 2012).

Therefore, although body size/biomass is relatively easy to measure and could provide a good indication of the potential key players driving a particular soil function, they only represent coarse groupings which do not take into account the fact that different soil organisms within the same size group could exhibit different physiological capabilities and that their relative importance in performing a specific function could change across temporal and spatial scales.

\section{REPRODUCTIVE STRATEGIES}

The way animals reproduce and their developing time or "lifehistory traits" also reflect the species' responses to environmental conditions (Moore et al., 1998) and therefore, provide important information on soil processes (Bongers and Bongers, 1998; Brussaard, 1998). For example, root feeding insects in temperate climates have often long life cycles because they have to cope with low quality plant material or its limited availability, whereas in tropical climates they tend to be multivoltine (Brown and Gange, 1990).

The most comprehensive classification using this criterion was provided by Siepel (1994) who described up to 12-life story tactics for soil microarthropods (primarily for mites, but Collembola were also used to validate his classification) based on four traits: 


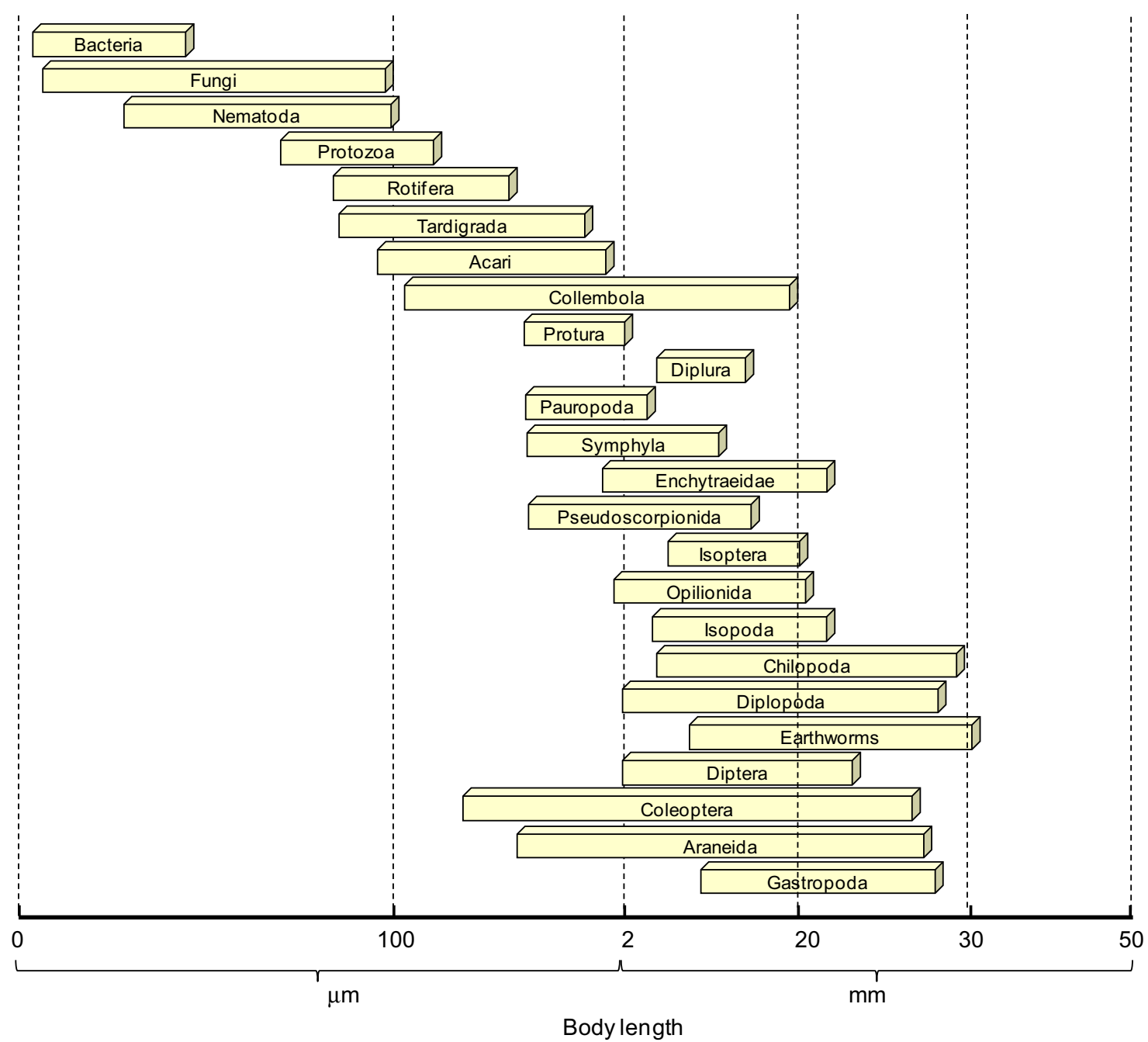

FIGURE 1 | Soil fauna size distribution using body length as a classifying criterion.

(i) Reproduction:

(a) Sexual or parthenogenesis [thelytoky (automictic or apomictic), arrhenotoky, amphitoky]

(b) Ovoposition timing: semelparity (on one occasion) and iteroparity (spread over time: continuous or seasonal)

(ii) Development (developmental stages and factors that control development): slow, moderate, fast, quite fast

(iii) Synchronization: diapause (obligate or facultative), aestivation and quiescence

(iv) Dispersal: phoresy (facultative and obligate, carrier-specific and carrier unspecific) and anemocory

Unfortunately, a similar detailed reproductive classification for other soil animal groups is not yet available. In addition, the fact that some species can exhibit more than one of these life-tactics and that some are either seasonal or facultative and therefore, could change under different environmental and food availability conditions, makes its practical use for linking reproductive diversity to a particular soil function rather limited.

\section{FEEDING}

Feeding perfectly describes the consumer-resource interaction and represents the fundamental basis of population-community ecology. In fact, the "guild" concept (Root, 1967) refers to "groups of species having similar exploitation patterns" and was later modified (Root, 1973) by adding "mode of feeding" as a secondary criterion. Both terms appear to be profusely used as synonyms in the literature (Hawkins and MacMahon, 1989), although the term "guild" appears to refer to a broader species classification than the term "functional group" (Brussaard, 1998).

The importance of feeding niches for describing different functional levels in soil communities is easily corroborated by the success of soil food-webs in modeling energy and nutrient transfers between the different compartments (e.g., Persson et al., 1980; Hunt et al., 1987; Moore and De Ruiter, 1991; De Ruiter 
et al., 1993, 1995; Bengtsson et al., 1995). The triumph of these models is derived from the causal-effect relationship between two of the parameters which are often included in these relationships: size/biomass and feeding/physiological rates, so that any alterations in their patterns would have a direct effect on processes rates (Bengtsson, 1998). However, one important drawback in these models (e.g., Hunt et al., 1987) is the assumption of soil fauna having a constant biomass, which is not realistic.

A good number of soil fauna classifications, based on feeding habits, have been proposed for different soil biota. They are in continuous revision and over the years, they have been either updated or completely renovated. The majority of them are "organism centered," but a few include the complete soil community. Some of these most influential schemes in ecological research are described below (see also Table 1).

A preliminary classification of soil Protozoa based on their preferred diets was proposed by Coûteaux and Darbyshire (1998) by adapting that previously developed by Pratt and Cairns (1985) for freshwater species. This was achieved by just adding the "mycophagous group" to the six ones already established (Table 1).

Yeates et al. (1993) identified eight feeding groups for nematodes in plant and soil systems according to their feeding habit or the food source (Table 1). Earlier on, Ferris (1982) described four different feeding groups within plant-parasitic nematodes, depending on their location and movement patterns and thus, (i) sedentary endoparasites were those that feed entirely within the root system in specialized feeding sites, (ii) migratory endoparasites feed along the root tissues, (iii) ectoparasites remain on the outside of the root and they can feed either superficially or on deeper tissues and finally, (iv) one intermediate category, the sedentary semi-endoparasitic nematodes which feed with its head deep inside in the vascular root tissues but with most of the body outside the root. Next, in order to get a better understanding of nematode roles in soil functioning, Bongers and Bongers (1998) combined this information and integrated nematode's life stories (from "colonizers" to "persisters") within the trophic classification, which resulted in further subdivisions of the plant feeders and animal predators (Table 1). In practice, a simplified system is applied, consisting of primary consumers (plant feeders), secondary consumers (bacterivores and fungivores), and tertiary consumers (predators and omnivores).

In the case of oribatid mites, Luxton (1972) summarized the available knowledge on nutritional biology of these organisms and developed a framework on the basis of their function being primarily litter fragmentation. Accordingly, he defined three major feeding habits: macrophytophages, microphytophages, panphytophages (Table 1), with the large majority of mites possibly belonging to the third group and hence, enabling them to colonize a wide range of habitats. In addition, because some oribatid mites were also seen to feed occasionally on other food sources, an additional category of feeding strategies was established (including zoophages, necrophages, coprophages; Table 1), but without being able to decide whether these alternative diets obeyed to a general rule, a random occurrence or were imposed by specific conditions (e.g., starvation). Interestingly, according to this study, the three major feeding groups exhibited different assimilation efficiencies which were likely to be in the order: macrophytophages $(10-15 \%)<$ panphytophages $(40-50 \%)<$ microphytophages $(50-65 \%)$ and hence, with potential different effects on soil processes.

However, due to increased awareness of the close interactions between oribatid mites and microbial populations (through grazing) and of their different digestive enzymatic capabilities, it became obvious that their ecological role could be two-fold: as primary decomposers by egesting a more readily decomposable substrate for microbial colonies and thus, serving as true "catalysts" (MacFadyen, 1964; Luxton, 1972), and as secondary decomposers by gaining their nutrition once it has been made more palatable by the microbiota (Luxton, 1972). Following this, Siepel and De Ruiter-Dijkman (1993) used the activities of three carbohydrases, able to degrade three important food components: cellulose (cell-walls of green plants), chitin (fungal cell-walls) and threalose (fungal cell-contents), as the main criteria for defining the feeding guilds of this particular group of mites. In their classification (Table 1), grazers (able to digest both cell-walls and contents) are clearly differentiated from "browsers" (capable of digesting cell-contents only). However, 11 years later, Schneider et al. (2004) simplified this framework and differentiated a total number of four feeding strategies for oribatid mites: phycophages/fungivores, primary decomposers (comminuting litter), secondary decomposers (consuming litter and fungi), and carnivores/scavengers/omnivores.

Because Collembola are typically considered to be fungivores, classifications based on their feeding habits are very scarce. For example, Addison et al. (2003) identified four collembolan feeding groups in a succession of Canadian coastal temperate forests on the basis of their gut contents and the most surprising finding was that, out of the four groups identified, one was not a fungal feeder but comprised species that ingested particulate organic matter. This is in agreement with other studies which also concluded that many species of Collembola are not fungal-feeders, but consumers of living or dead plant tissue or liquids, algae, pollen grains and even other soil biota such as Protozoa, Rotatoria, enchytraeids and nematodes (e.g., Rusek, 1998; Chamberlain et al., 2005, 2006).

The possibility that previous assumptions on soil animal's diets might not reflect reality was also confirmed by other studies which suggested the possibility that earthworms may also digest protozoans, nematodes and even enchytraeids (Gorny, 1984; Roesner, 1986; Bonkowski and Schaefer, 1997). This seems to suggest that predation could be a wider spread feeding strategy in soils than previously assumed, also complicated by the coexistence of cannibalism and intra-guild predation (Polis, 1991). Scheu and Setälä (2002) concluded that the difficulties in finding preys in the opaque and porous soil environment and the inability of potential preys to acquire evolutionary traits to avoid predation by specific predators might explain why soil predators have been usually considered as "generalist feeders." In relation to this, the "trophic cascade theory" or "top-down regulation" has been profusely applied when describing soil food-webs and according to it, prey populations sizes are closely related to that of their prey. However, the effect of increased predation and subsequent reduction in population numbers of potential preys on soil processes 
Table 1 | Functional classifications of different soil invertebrates based on different criteria and including the definition of the proposed groups.

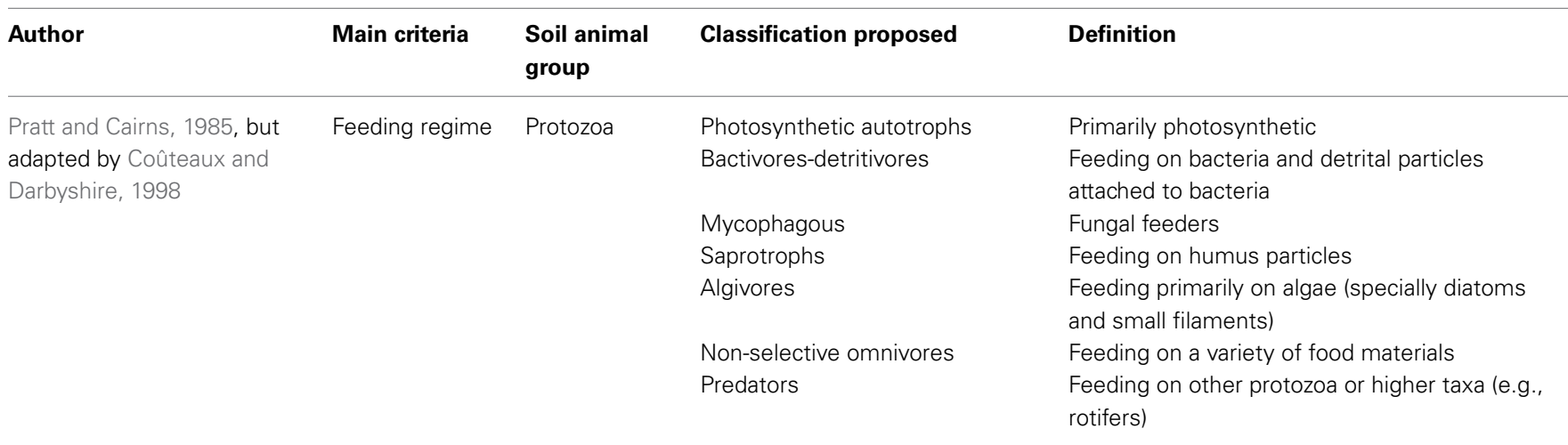

Yeates et al., 1993, updated by Bongers and Bongers (1998)
Feeding habit Nematodes Plant feeders and food source
Feeding on vascular plants. They could be subdivided into six groups: (i) sedentary parasites, (ii) migratory endoparasites, (iii) semi-endoparasite, (iv) ectoparasites, epidermal cell and root hair feeders, (v) algal, lichen or moss feeders, (vi) feeders on above-ground plant tissue

Fungal feeders

Bacterial feeders

Substrate ingester

Animal predators

Unicellular eucaryote feeders

Dispersal or infective stages of animal parasites

Omnivores
Feeding on hyphae of saprophytic fungi

Feeding on any prokaryote food source More than a pure food source is ingested, possibly incidentally

Feeding on invertebrates (e.g., protozoa, nematode, rotifer and enchytraeids) either as (i) ingesters or (ii) piercers

Feeding on diatoms or other algae, fungal spores and whole yeast cells Entomogenous species

Feeding on a wide range of foods

Macrophytophages

Microphytophages

Feeding on plant material: (phyllophages) or wood (xylophages) tissues

Feeding on microbiota: fungi and yeasts (mycophages), bacteria (bacteriophages) or algae (phycophages)

Panphytophages

Zoophages

Necrophages

Feeding on all kinds of plant or fungal tissues

Feeding on living animal material

Feeding on carrion

Coprophages

Feeding on fecal material $\begin{array}{lll}\begin{array}{l}\text { Siepel and De Ruiter-Dijkman, } \\ 1993 \\ \text { activity }\end{array} & \text { Oribatid mites Herbivorous grazers }\end{array}$
Herbivorous browsers

Fungivorous grazers

Fungivorous browsers

Herbo-fungivorous grazers

Oportunistic herbo-fungivorous
Cellulase activity: feeding on both cell-walls and cell-contents of plants (including algae) Lacking carbohydrase activity: carrion feeders and bacteria feeders

Chitinase and threolase activities: feeding on both cell-walls and cell-contents of fungi Threalose activity: feeding on lichens and cell-contents of fungi

Cellulase, chitinase and threalose activities: feeding on all kind of green plants and fungi Cellulase and threolase activities: feeding on green plants but taking advantage of periodic increases in fungal growth in their biotopes (the semi-aquatic group could also feed on cyanophyta and those living on moss on trees or stones, dropped cones, etc., might also feed on lichens) 
Table 1 | Continued

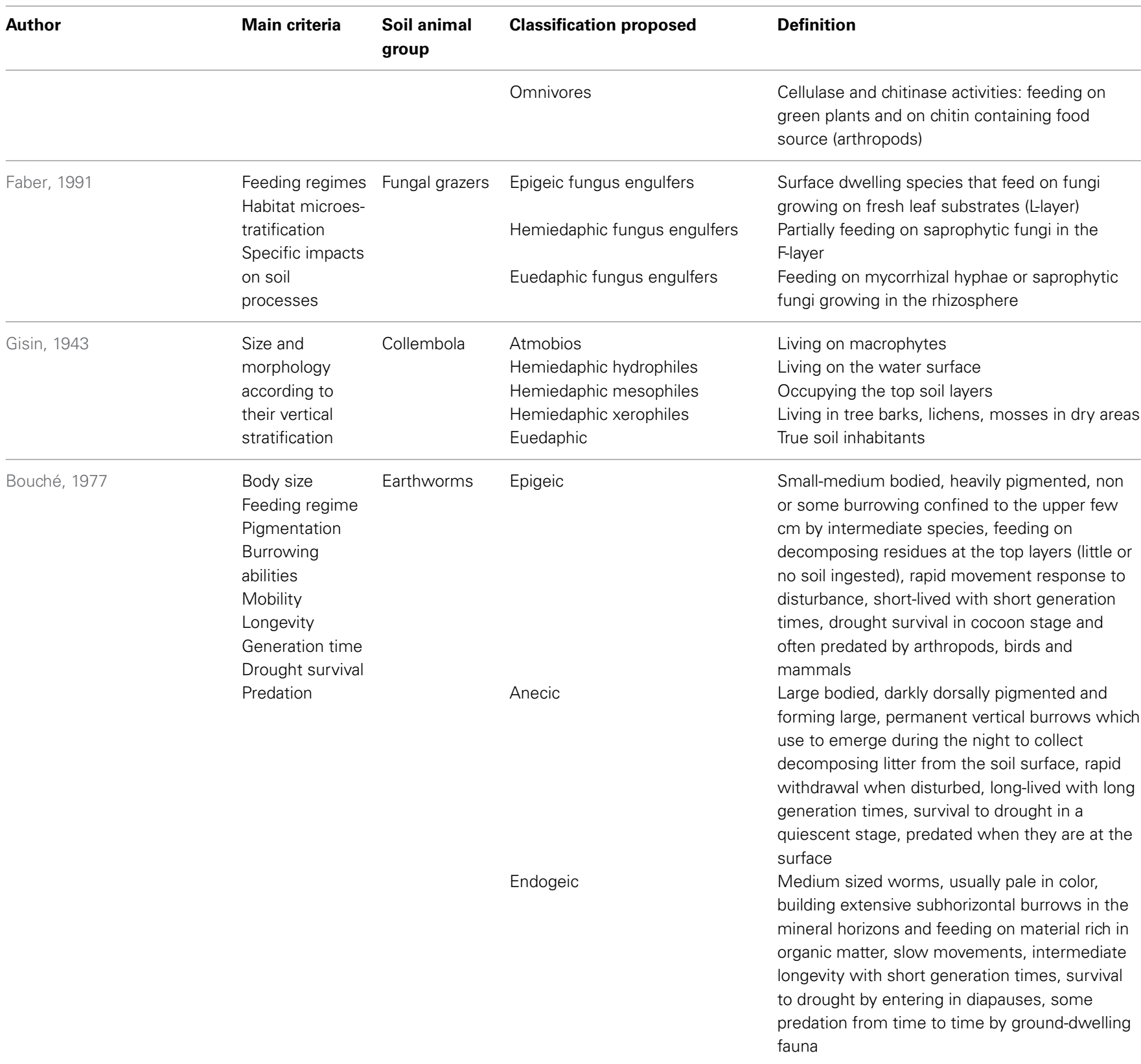

Lavelle, 1983

Quality of
organic matter
ingested

Endogeic

Earthworms

ingested
Polyhumic endogeics

Mesohumic endogeics

Oligohumic endogeics
Fairly pigmented, large bodied and form burrows, feeding on soil with high organic content

Unpigmented and otherwise are intermediate, feeding on mineral and organic particles Unpigmented, large bodied, have no escape behavior and feed on deeper horizons with low organic matter content

Feeding on undecayed substrates: wood (wet and dry), grass and detritus in the same discrete substrate where they also nest; having mutuallistic flagellates in their guts Feeding on undecayed substrates: wood (wet and dry), grass and detritus in the same discrete
Feeding Group l-intermediate nesters 
Table 1 | Continued

\begin{tabular}{|c|c|c|c|c|}
\hline Author & Main criteria & $\begin{array}{l}\text { Soil animal } \\
\text { group }\end{array}$ & Classification proposed & Definition \\
\hline & & & & $\begin{array}{l}\text { substrate where they also nest, but also forage } \\
\text { in other patches away from the colony center; } \\
\text { having mutuallistic flagellates in their guts }\end{array}$ \\
\hline & & & $\begin{array}{l}\text { Feeding Group I-separate piece } \\
\text { nesters }\end{array}$ & $\begin{array}{l}\text { Feeding on undecayed substrates: wood (wet } \\
\text { and dry), grass and detritus away from their } \\
\text { nest; having mutuallistic flagellates in their guts }\end{array}$ \\
\hline & & & $\begin{array}{l}\text { Feeding Group II-intermediate } \\
\text { nesters }\end{array}$ & $\begin{array}{l}\text { Feeding on undecayed substrates: wood, } \\
\text { fungus, grass, detritus, litter and microepiphytes } \\
\text { in the same discrete substrate where they also } \\
\text { nest, but also forage in other patches away from } \\
\text { the colony center; no flagellates in their guts }\end{array}$ \\
\hline & & & Feeding Group II-separate nesters & $\begin{array}{l}\text { Feeding on undecayed substrates: wood, } \\
\text { fungus, grass, detritus, litter and } \\
\text { microepiphytes, away from their nest; no } \\
\text { flagellates in their guts }\end{array}$ \\
\hline & & & Feeding Group III & $\begin{array}{l}\text { "Humus feeders": feeding on the soil-wood } \\
\text { interface and soil (some visible plant fragments } \\
\text { present in their guts) }\end{array}$ \\
\hline & & & Feeding Group IV & $\begin{array}{l}\text { Feeding on soil only (no visible plant remains } \\
\text { present in their guts) }\end{array}$ \\
\hline \multirow{9}{*}{$\begin{array}{l}\text { Greenslade and Halliday, } \\
\text { 1983; Andersen, 1990, 1995, } \\
\text { 1997; Folgarait, 1998; Brown, } \\
2000\end{array}$} & \multirow{9}{*}{$\begin{array}{l}\text { Biogeography } \\
\text { and habitat } \\
\text { requirements } \\
\text { Relative } \\
\text { behavioral } \\
\text { dominance }\end{array}$} & \multirow[t]{9}{*}{ Ants } & Dominant Dolichoderinae & $\begin{array}{l}\text { Abundant, highly active and aggressive species, } \\
\text { very strong competitors with other ants; prefer } \\
\text { hot and open habitats }\end{array}$ \\
\hline & & & Subordinate Camponotini & $\begin{array}{l}\text { Co-occurring with, and behaviorally submissive } \\
\text { to, Dominant dolichoderines; large body size, } \\
\text { often foraging at night }\end{array}$ \\
\hline & & & Hot climate specialists & $\begin{array}{l}\text { Arid-adapted taxa with morphological, } \\
\text { physiological or behavioral specializations to } \\
\text { reduce interactions with Dominant } \\
\text { dolichoderines }\end{array}$ \\
\hline & & & Cold climate specialists & $\begin{array}{l}\text { Cold and temperate-adapted taxa, occurring in } \\
\text { habitats where Dominant dolichoderines are } \\
\text { generally not abundant }\end{array}$ \\
\hline & & & Tropical climate specialists & $\begin{array}{l}\text { Distribution centered in the humid tropics, in } \\
\text { particular in those habitats where Dominant } \\
\text { dolichoderines are generally not abundant }\end{array}$ \\
\hline & & & Cryptic species & $\begin{array}{l}\text { Taxa foraging predominantly in the soil and litter } \\
\text { layers, having relatively little interaction with } \\
\text { epigenic ants }\end{array}$ \\
\hline & & & Opportunists & $\begin{array}{l}\text { Unspecialized, ruderal taxa, characteristic of } \\
\text { disturbed sites or other habitats with low ant } \\
\text { diversity }\end{array}$ \\
\hline & & & Generalized Myrmicinae & $\begin{array}{l}\text { Cosmopolitan genera occurring in most habitats; } \\
\text { sub-dominant ants with the ability for rapid } \\
\text { recruitment and successful defense of clumped } \\
\text { food resources }\end{array}$ \\
\hline & & & Specialist predators & $\begin{array}{l}\text { Large body size but small colony size; little } \\
\text { interaction with other ants due to their } \\
\text { specialist diet }\end{array}$ \\
\hline
\end{tabular}

appears to be either a major controlling agent (Fitter et al., 2005), undetectable (e.g., Laakso and Setälä, 1999) or even inhibitory (Cortet et al., 2002).

To date, a tentative classification of the feeding habits enchytraeid does not exist and much of the research effort is still being placed in trying to determine their preferential diet. For example, while some studies suggest they are fungivorous rather than bacteriovorous (Standen and Latter, 1977; Krištůfek et al., 2001), others showed that they are also saprovores (Briones and Ineson, 2002). 
A possible reason for this gap in knowledge in soil animals' feeding ecology is the difficulties associated with accurate assessing of the feeding preferences of soil organisms. Advances in describing soil animal diets and trophic interactions have been gained from stable isotope techniques, which provide an accurate estimate of their assimilated diet (i.e., the isotopic composition of animal tissues reflects that of the animals' diet). In research on soil animals, isotope ratios of carbon (expressed as $\delta^{13} \mathrm{C}$ ) and nitrogen $\left(\delta^{15} \mathrm{~N}\right)$, either as bulk or compound specific, have provided valuable information on the dietary preferences for certain groups (e.g., Briones et al., 1999; Tayasu et al., 2002; Ruess et al., 2004; Schneider et al., 2004; Chamberlain et al., 2005, 2006). However, despite being promising tools, several ontogenetic, physiological and biochemical factors can affect the isotopic composition of the animal tissues (reviewed by Briones and Schmidt, 2004). As a result, species from putative different trophic groups, such as collembolans, oribatid mites, diplopods and earthworms, could show similar range of isotopic values and thus, suggesting similar food resource preferences (Scheu and Falca, 2000).

\section{COMBINING FEEDING PREFERENCES WITH OTHER ECO-BEHAVIORAL ASPECTS}

Because the same functional group could exploit different feeding habitats as a result of their vertical stratification along the soil profile (Walter et al., 1988), "feeding guild" provides a coarse classification and a new concept, "league" was coined instead (Faber, 1991), which incorporates microhabitat distributions together with feeding preferences. Accordingly, " a league is a group of organisms, not necessarily taxonomically related, that exploit and process more than one habitat resource in a homologous manner." This implies that soil organisms should be classified according to two axes, food/feeding strategies and microhabitat preference, which will result in a stratified soil community. For example, the three leagues comprising the fungus grazing fauna (i.e., nematodes, mites and some collembolans and enchytraeids) have different feeding preferences along the fresh, fragmented and humus layers (Table 1).

One of the earliest efforts to integrate the vertical distribution of soil organisms within a functional classification was proposed by Gisin (1943) who differentiated several "life forms" of Collembola according to their habitat adaptations and soil stratification (Table 1). However, not all collembolan species show a life strategy reflecting their morphology (e.g., Takeda, 1995) and for example, smaller-sized animals tend to prefer deeper layers, possibly due to juveniles and tiny animals being more sensitive to desiccation than their adults (Verhoef and Witteveen, 1980). Furthermore, down-ground migration could be just a survival strategy in response to lowered soil moisture levels during dry periods and different sized invertebrates such as collembolans (Detsis, 2000), enchytraeids (Briones et al., 1997) and termites (Lavelle et al., 1997) find refuge in the deeper layers.

Bouché (1977) used the differences in vertical distribution of earthworms along with other physiological and behavioral characteristics (body size, food, pigmentation, burrowing, mobility, longevity and generation time, drought survival, and susceptibility to predation) to establish three "ecological" groupings among European lumbricids (Table 1). Interestingly, the differences in burrowing abilities exhibited by earthworms led Keudel and Schrader (1999) to measure the axial and radial pressures exerted when penetrating the soil and found that they were actually different: $14-25$ and $39-63 \mathrm{kPa}$ for epigeics, $46-65$ and $72-93 \mathrm{kPa}$ for anecic and 26-39 and $59-195 \mathrm{kPa}$ for endogeics. However, Lavelle (1979) argued that not all earthworms fit within these categories since that, for example, in tropical savannahs the majority of the earthworms are either endogeic or intermediate between epigeic and endogeic and thereby, he subdivided the endogeic group into "epiendogeic," living in the upper soil horizons and "hypoendogeic," living in the deeper ones. A few years later, Lavelle (1983) completed his previous work and defined three endogeic categories based on the degree of humification of the organic matter ingested (Table 1). Interestingly, he also found that the relative abundance of these functional groups varied along a thermo-latitudinal gradient, with cold climates being dominated by both epigeic and polyhumic endogeic worms and as temperature increases they become gradually integrated by anecics and mesohumic and oligohumics endogeics able to digest lower quality resources (Lavelle, 1983).

The first functional classification of termites was proposed by Abe (1987) on the basis of their overlap in feeding and nesting strategies and consisted of four different groups: (i) single piece nesters (those that feed and nest in the same substrate), (ii) intermediate nesters (although feeding and nesting in a specific location, they also forage outside their colony center), (iii) separate-piece nesters (actively seek for their nutrition away from the nest), (iv) soil feeders (those that feed and nest in the soil). Some years later, Donovan et al. (2001) matched the anatomical aspects of the workers with their gut content analyses and defined four feeding groups distributed along a humification gradient: (i) feeding on wood, litter and grass (only in non-Termitidae), (ii) feeding wood, litter and grass (only in Termitidae), (iii) feeding on very decayed wood or high organic content soil (only in Termitidae) and (iv) true soil feeders. Finally, Eggleton and Tayasu (2001) combined these two existing schemes into a "two-way lifeway" classification (Table 1), after considering that the substrate's humification and position in relation to the nest center have more ecological importance than the substrate itself. A link with soil processes was provided by Rückamp et al. (2010), who concluded that organic $\mathrm{P}$ dominates the $\mathrm{P}$ fraction in the xilophagous (feeding group II) termite nests, whereas the inorganic forms tend to dominate in the humivores (feeding group III) and grass-feeder (feeding group II) ones. Conversely, in an earlier study (Wood, 1988), it was shown that the nature of the original materials used by termites to build their structures, rather than their feeding habits, has a more crucial role in $\mathrm{N}$ fixation and thus, in those nests made of carton (a mixture of faces and macerated wood fiber) $\mathrm{N}$ is actively fixed and C: $\mathrm{N}$ ratios can range from 20:1 to $100: 1$, whereas an absence of $\mathrm{N}$ fixation appears to characterize those structures made using highly decayed wood or SOM.

Ants are largely considered to be omnivores and opportunistic feeders, although some subfamilies and genera also include general predators as well as specialized predators (e.g., preferring collembolans, termites or ants) and herbivorous (feeding on seeds, honeydew, plant nectar, and leaves, etc.). Consequently, their communities are better described as a continuum from 
predominantly vegetarian taxa to purely predators with a high degree of omnivory (Blüthgen et al., 2003; Gibb and Cunningham, 2011). Furthermore, their relative trophic positions are considered to be relatively conservative but their community assemblage (species composition) rather flexible in its use of the available resources, which may result in higher resilience to land use changes (Gibb and Cunningham, 2011). However, other studies suggest that ant assemblages are very sensitive to human impacts and can act as indicators of habitat perturbations, successional stages and land use and climate changes (e.g., Andersen, 1997; Folgarait, 1998; Gómez et al., 2003). This is also the consequence of their overlapping foraging requirements and hence, feeding, as a single criterion, does not adequately describe the huge diversity and behavioral adaptations within the ant communities. As a result, the current functional classification of ants is based in the successive additions of other classificatory factors such as demography, climate and soil type (Greenslade and Halliday, 1983; Andersen, 1990, 1995, 1997, 2000; Brown, 2000) and includes seven different functional groups, one of them with three subdivisions (Table 1). This scheme has been considered to be advantageous in reducing the complexity of the ecological systems and in enabling a basis for evaluating environmental change in relation to ant community structure (Vineesh et al., 2007).

\section{ESTABLISHING THE PECKING ORDER: CHOOSING THE RULING TEAM}

Lavelle (1996) was the first one to produce a "hierarchical" model of soil biota by combining, on one hand, the effects of certain biological structures on the biodiversity of smaller organisms and on soil processes and on the other, their feeding regime (Table 2). Accordingly, at the lowest level, the "microbiota" act upon organic matter and nutrient cycles, root and rhizosphere processes and plant production (with both positive and negative effects). Next, the "micropredators," being primarily microfauna, such as nematodes and protozoa, do not produce any physical structures and survive by predation on microbiota and other organisms and thus, they stimulate mineralization of organic matter and plant nutrient availability. At a higher level, "litter transformers," including many macro- (Diplopoda, Chilopoda, Isopoda or insects) and micro-arthropods (mites and collembolans), enchytraeid worms and other detritus feeders, stimulate the breakdown and decomposition of surface litter and organic matter, producing small, rather fragile and primarily organic fecal pellets. Finally, "ecosystem engineers," comprising big-sized organisms (termites, ants and earthworms) and whose bioturbating activities produce structures that can last long periods of time (outlasting the organisms that produced them), affect SOM dynamics and soil physical processes. The most remarkable aspect of this classification is the fact that it takes into account the potential top-down regulatory controls of larger organisms (e.g., the ecosystem engineers) over smaller ones. The greater importance given to the biogenic structures produced by ecosystem engineers is two-fold: (i) their effects on soil processes spread along spatial and temporal scales: nutrient mineralization (microsites for microorganisms), physical stabilization (hydrological properties, resistance to erosion) and chemical stabilization (humification and nutrient retention) of organic matter (Lavelle et al., 1997) and (ii) they can be differentiated from the surrounding bulk soil and constitute true functional domains (Lavelle, 2002): "termitosphere" (termites), "myrmecosphere" (ants) and "drilosphere" (earthworms).

Surface mixing by soil invertebrates have been suggested to be one of the most important soil processes (Mulder, 2006) and in particular, casting activities of annelids (including the families Lumbricidae and Enchytraeidae) have long been recognized as one of the main determinants of soil structure. For example, in tropical soils, under some circumstances, the top layers merely consist of earthworm casts of different ages (Lavelle, 1988) and in organic grasslands $90 \%$ of the SOM is processed by a few species of earthworms and enchytraeids (Davidson et al., 2002). However, one aspect of Lavelle's classification which deserves some attention is the importance given to the life-span of these cast materials and which allows the differentiation between ecosystem engineers and litter transformers. In Lavelle's study it is stressed that, in the case of the latter group, their casts being predominantly organic, makes them highly susceptible to be ingested by other soil invertebrates and thus, very unlikely to have significant effects in the longer term (Lavelle et al., 1997). Thus, it has been observed that the endogeic earthworm species Octolasion lacteum can obtain additional nutritional value from the fecal material produced by millipedes (Bonkowski et al., 1998). In contrast, other studies have shown that mite fecal pellets can persist in the soil profile for a long time and release nitrogen very slowly (Pawluk, 1987), and Heisler et al. (1996) found increased aggregate stability of casts from Collembola compared with soil aggregates. Furthermore, different species of endogeic earthworms can produce different cast material with different stability, and this aspect was used by Blanchart et al. (1999) to classify them into two functional groups: "compacting" earthworm species that produce large and stable "globular" casts and de-compacting worms that produce fragile "granular" casts and partially feed on large compact casts (Table 2). Consequently, the life-spans of these structures and their impact on soil structure and ecological processes highly depend on the organic content of the soil and of the food consumed as well as on the intensity of the faunal activities (Lavelle et al., 1997).

The concept of "ecosystem engineering" has been widely accepted by the scientific community, possibly because this eyecatching term perfectly summarizes the long known fact that living organisms can create and structure habitats and modulate resources' availability. However, it is no without problems, mostly associated with deciding by which process (physical, chemical, assimilatory/dissimilatory) soil organisms modify their environment and hence, removing the possibility that nearly every organism could be included under this term. For example, Berke (2010) defined four subcategories, with only three of them actually applying to terrestrial systems (i.e., "structural," "bioturbators," and "chemical" engineers; Table 2). However, according to this classification, and in the case of the soil biota, these subdivisions tend to overlap and for example, plants are both structural and chemical engineers, termites and ants are structural engineers as well as bioturbators; the only exceptions are earthworms which are only classified as burrowers and mycorrizal fungi as chemical engineers (Table 2). 
Table 2 | Functional classifications based on the pivotal role of ecosystem engineers.

\begin{tabular}{|c|c|c|c|c|c|}
\hline Author & Main criteria & $\begin{array}{l}\text { Soil animal } \\
\text { group }\end{array}$ & $\begin{array}{l}\text { Classification } \\
\text { proposed }\end{array}$ & Definition & $\begin{array}{l}\text { Implications for ecosystem } \\
\text { functioning }\end{array}$ \\
\hline \multirow[t]{4}{*}{ Lavelle, 1996} & \multirow[t]{4}{*}{$\begin{array}{l}\text { Physical } \\
\text { structures } \\
\text { Effects on } \\
\text { biodiversity } \\
\text { Effects on } \\
\text { function }\end{array}$} & \multirow[t]{4}{*}{$\begin{array}{l}\text { Roots and soil } \\
\text { invertebrates }\end{array}$} & Roots & $\begin{array}{l}\text { Creating rhizosphere structures; } \\
\text { effects on biodiversity by } \\
\text { secreting polysaccharides, } \\
\text { selecting microbiota, associating } \\
\text { food-webs and attracting } \\
\text { root+root litter feeders }\end{array}$ & Enhanced mineralization \\
\hline & & & Micropredators & $\begin{array}{l}\text { No physical structures, effects on } \\
\text { biodiversity by microbial grazing }\end{array}$ & Enhanced mineralization \\
\hline & & & $\begin{array}{l}\text { Litter } \\
\text { transformers }\end{array}$ & $\begin{array}{l}\text { Producing organic fecal pellets; } \\
\text { effects on biodiversity by } \\
\text { selecting microbiota, creating } \\
\text { microhabitats for smaller } \\
\text { invertebrates and providing food } \\
\text { for other invertebrates }\end{array}$ & $\begin{array}{l}\text { Enhance mineralization and SOM } \\
\text { sequestration (depending on } \\
\text { time scale) }\end{array}$ \\
\hline & & & $\begin{array}{l}\text { Ecosystem } \\
\text { engineers }\end{array}$ & $\begin{array}{l}\text { Building large compact } \\
\text { organo-mineral structures, } \\
\text { smaller aggregates and a large } \\
\text { variety of pores (galleries, } \\
\text { burrows and chambers); effect } \\
\text { on biodiversity by selecting } \\
\text { microbiota and/or litter } \\
\text { transformers and promoting root } \\
\text { development }\end{array}$ & $\begin{array}{l}\text { Bioturbation, dissemination of } \\
\text { fungal spores, regulation of } \\
\text { structural porosity and aeration, } \\
\text { aggregation (compaction or } \\
\text { decompaction), infiltration rates, } \\
\text { water storage capacity, root } \\
\text { growth, SOM transformations } \\
\text { and nutrient cycling }\end{array}$ \\
\hline \multirow[t]{2}{*}{$\begin{array}{l}\text { Blanchart } \\
\text { et al., } 1999\end{array}$} & \multirow[t]{2}{*}{ Casts } & \multirow[t]{2}{*}{$\begin{array}{l}\text { Endogeic } \\
\text { earthworms }\end{array}$} & Compacting & $\begin{array}{l}\text { Producing large (>2 mm) } \\
\text { "globular" casts and large } \\
\text { macropores }\end{array}$ & $\begin{array}{l}\text { Increased soil compaction and } \\
\text { water retention capacity, } \\
\text { decreased infiltration rate }\end{array}$ \\
\hline & & & Decompacting & $\begin{array}{l}\text { Producing small (<2 mm) } \\
\text { "granular" casts and small } \\
\text { macropores }\end{array}$ & $\begin{array}{l}\text { Increased soil porosity, } \\
\text { breakdown of the large } \\
\text { aggregates, infiltration rate and } \\
\text { decreased water retention } \\
\text { capacity }\end{array}$ \\
\hline \multirow[t]{2}{*}{ Berke, 2010} & & \multirow{2}{*}{$\begin{array}{l}\text { Most plants } \\
\text { and mound- } \\
\text { building } \\
\text { insects } \\
\text { Earthworms, } \\
\text { ants and } \\
\text { termites } \\
\text { Most plants, } \\
\text { mycorrhizal } \\
\text { fungi }\end{array}$} & $\begin{array}{l}\text { Structural } \\
\text { engineers }\end{array}$ & & $\begin{array}{l}\text { Create living space, reduce } \\
\text { disturbance, alter hydrodinamics, } \\
\text { sedimentation and diversity } \\
\text { (usually by enhancing it) }\end{array}$ \\
\hline & & & $\begin{array}{l}\text { Chemical } \\
\text { engineers }\end{array}$ & & $\begin{array}{l}\text { Enhance disturbance, mix } \\
\text { sediment, alter biogeochemistry } \\
\text { and diversity (usually by reducing } \\
\text { it) } \\
\text { Create biogeochemical gradients } \\
\text { (physically or physiologically) }\end{array}$ \\
\hline \multirow[t]{3}{*}{$\begin{array}{l}\text { Hedde et al., } \\
2005\end{array}$} & \multirow[t]{3}{*}{$\begin{array}{l}\text { Casts } \\
\text { Nests } \\
\text { Mounds }\end{array}$} & \multirow[t]{3}{*}{$\begin{array}{l}\text { Earthworms } \\
\text { Ants } \\
\text { Termites }\end{array}$} & $\begin{array}{l}\text { Accumulators } \\
\text { of protected } \\
\text { organic matter }\end{array}$ & $\begin{array}{l}\text { Carton termite mounds showing } \\
\text { high protection of organic matter } \\
\text { and high potential mineralization } \\
\text { rates }\end{array}$ & $\begin{array}{l}\text { They might represent } \\
\text { a pool of protected organic matter }\end{array}$ \\
\hline & & & $\begin{array}{l}\text { Soil } \\
\text { compactors }\end{array}$ & $\begin{array}{l}\text { Organo-mineral termite mounds } \\
\text { and earthworm casts with low } \\
\text { concentrations of organic matter } \\
\text { and mineralization rates }\end{array}$ & $\begin{array}{l}\text { Higher efficiency and longer } \\
\text { stability of the protected organic } \\
\text { matter }\end{array}$ \\
\hline & & & $\begin{array}{l}\text { Soil } \\
\text { decompactors }\end{array}$ & $\begin{array}{l}\text { Ant mounds and termite } \\
\text { sheathings with loose structure } \\
\text { and low organic content and } \\
\text { mineralization rates }\end{array}$ & $\begin{array}{l}\text { Limited action on organic matter } \\
\text { dynamics but greater influence } \\
\text { on physical properties by } \\
\text { disaggregating organo-mineral } \\
\text { complexes }\end{array}$ \\
\hline
\end{tabular}


Hedde et al. (2005) used a different approach, the molecular composition of the organic matter present in the different biogenic structures produced by ecosystem engineers and its relationships with selected biological and chemical characteristics, to differentiate between three functional groups of engineers (Table 2). In this classification, groups were established according to: (i) whether the structures were produced after gut transit (earthworm casts, mounds built by humivorous termites) or by displacement of soil particles (ant nests and termite sheathings), (ii) whether intestinal mucus or saliva have been added (earthworm casts and termite mounds and sheathings) or they were merely an aggregation of separated soil particles (ant nests) and (iii) whether the effect of microbial activities (either by mutualistic association with the gut of the engineer or by colonization of the fresh biostructures) changed the molecular composition of SOM.

There are others who claim that the ecosystem engineering concept should couple the abiotic environment with the population dynamics feedback (Cuddington et al., 2009). For example, in the case of the burrowing fauna (e.g., earthworms), they should be considered as "obligate engineers" since they have to build their burrows in order to survive; however, if worm densities reach high values, the resulting intensive burrowing activity could negatively affect the stability of the substrate and in turn, species population dynamics. One illustrative example can be found in tropical soils, where the activities of the earthworm Amynthas hawayanus reduce the SOM content at the top layers and could result in water runoff and soil erosion (Burtelow et al., 1998). Similarly, ants could build two types of mounds with different pedological impacts (Paton et al., 1995): (i) type I, being small in size and crater-shaped and consisting of sand particles linked by a clay matrix and very susceptible to erosion and (ii) type II, being large size and elliptical shape and made of reworked material and highly resistant to erosion.

Another interesting example is the one provided by the peregrine invasive earthworm species Pontoscolex corethrurus, which has successfully colonized pastures after forest conversion in the humid tropics and, during the rainy season, its engineering activities result in the formation of a surface soil crust (compact and asphyxiating horizon of $2-5 \mathrm{~cm}$ thick and produced by coalescence of a large amounts of casts with a high water content and a muddy structure) through which it cannot feed (Blanchart et al., 1999; Chauvel et al., 1999; Jouquet et al., 2006). This state also results in profound alterations in water infiltration and promotes methane production; however, it is reversible and if decompacting species, with their antagonistic effects, are present or organic residues are added, the soil structure can be conserved (Blanchart et al., 1999). This contrasts with its role in other ecosystems, where this same species improves soil structure and fertility (Marichal et al., 2010).

The direction of the feedback effects of these engineering activities (positive or negative) was used by Jones et al. (1994, 1997) to distinguish between "extended phenotype engineers" (recalling the work by Dawkins, 1982), whose structures have a positive effect on the organism growth, and "accidental engineers," whose activities do not have a positive effect on themselves. The former typically include those social species (e.g., termites and ants) which build mounds and nests that clearly benefit their fitness, whereas the biogenic structures of the earthworms could or could not have a direct positive effect on themselves and hence,

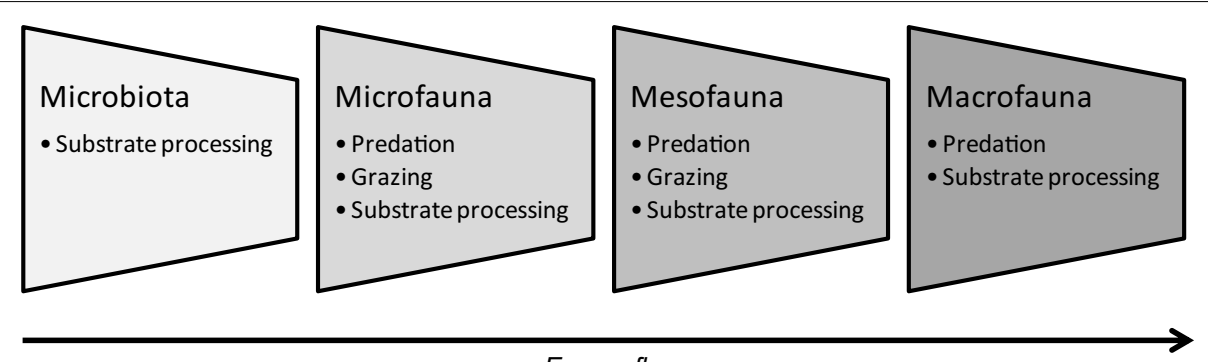

Energy flow

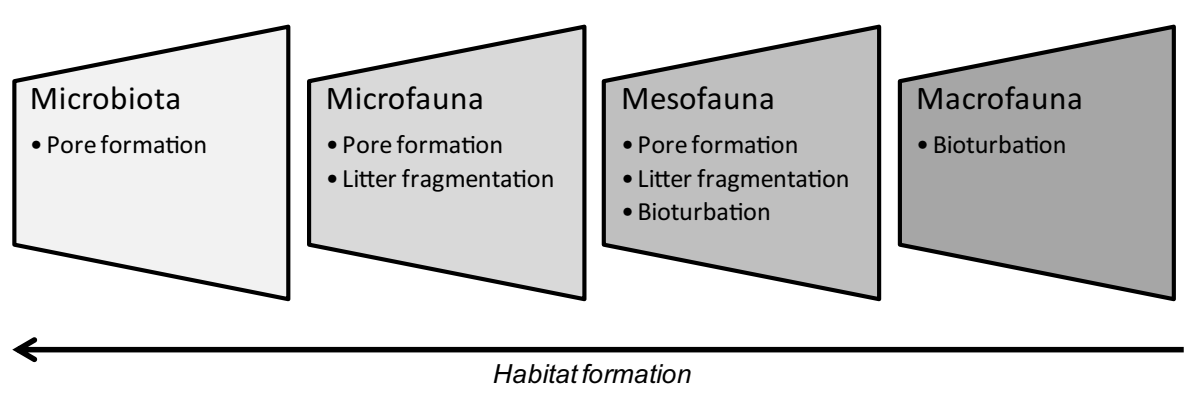

FIGURE 2 | Trophic and engineering interactions among soil organisms based on their body size (adapted from Scheu and Setälä, 2002, with permission from Cambridge University Press). 
depending on the species they could be included in either group (Jouquet et al., 2006).

Another way of integrating the influences of both engineers and smaller organisms on soil processes is by converting them into complementary transferring actions over a time scale. Accordingly, because the engineer activities regulate the provision of nutrients to other organisms, they have an indirect effect on trophic interactions and hence, on energy flow. Consequently, the action of small organisms can be viewed as "energy transfer agents" in the short term, whereas engineering activities act as "habitat agents" in the longer term (Scheu and Setälä, 2002; Figure 2).

\section{INCORPORATING THE ABOVE-GROUND ENGINEERS: ROLE OF PLANTS IN TEAM PERFORMANCE}

Linking the interactions between the above- and below-ground biota, the so-called "holistic view" of the ecosystem is becoming increasingly accepted (e.g., De Deyn and Van der Putten, 2005; Huhta, 2007). The role of plants in soil processes is so relevant that they can also be considered as ecosystem engineers since they also create suitable habitats for other organisms (Lavelle et al., 1993; Brussaard, 1998; Lavelle, 2002; Berke, 2010). Plants influence below-ground processes (e.g., SOM decomposition and nutrient cycling) in several ways, through litter quality, root exudation and mycorrizal association, all of which have been considered to be "functional attributes" or "functional traits." As a consequence, the functional characteristics of the above-ground of dominant plant species are more important than the species richness (e.g., Hooper et al., 2005). For example, different plants support different bacterial communities, both beneficial and pathogenic, and hence, plant performance and resistance (Hartmann et al., 2008) and root exudates are known to attract soil fauna activities. The importance of understanding soil organisms in the context of their microhabitat has led to include the "rhizosphere" as a distinct "functional domain" from the "litter system" (Hiltner, 1904; Lavelle, 2002). These functional domains recall two of the "spheres of influence" of soil biota defined by Brussaard et al. (1997): "rhizosphere" or "root biota," and "decomposers" (also called "litter transformers" or "shredders").

The fact that bacterial communities close to the roots are very different from those in the bulk soil (Marilley and Aragno, 1999) confirms this functional dissimilarity. Similarly, the "mycorrhizosphere" (the volume immediately surrounding the mycorrhizas associated to the roots) also concentrates specific bacterial communities with contrasting functional characteristics from the surrounding soil (Uroz et al., 2013). By influencing the root recognition and receptivity of the mycobiont, the fungal growth and propagation as well as modifying the surrounding soil they can improve the quality of the mycorrhizal association and thus, deserving the consideration of "mycorrhization helper bacteria" (Rigamonte et al., 2010).

Interestingly, these two domains or spheres are considered to be both mutualistic and complementary and thus, while active microbial grazers in the rhizosphere (such as protozoans and nematodes) function as "bacteria-mediated mutualists" by facilitating the liberation of essential nutrients for plant growth (e.g., nitrogen), in the mycorrhizal mutualism the plant transfers

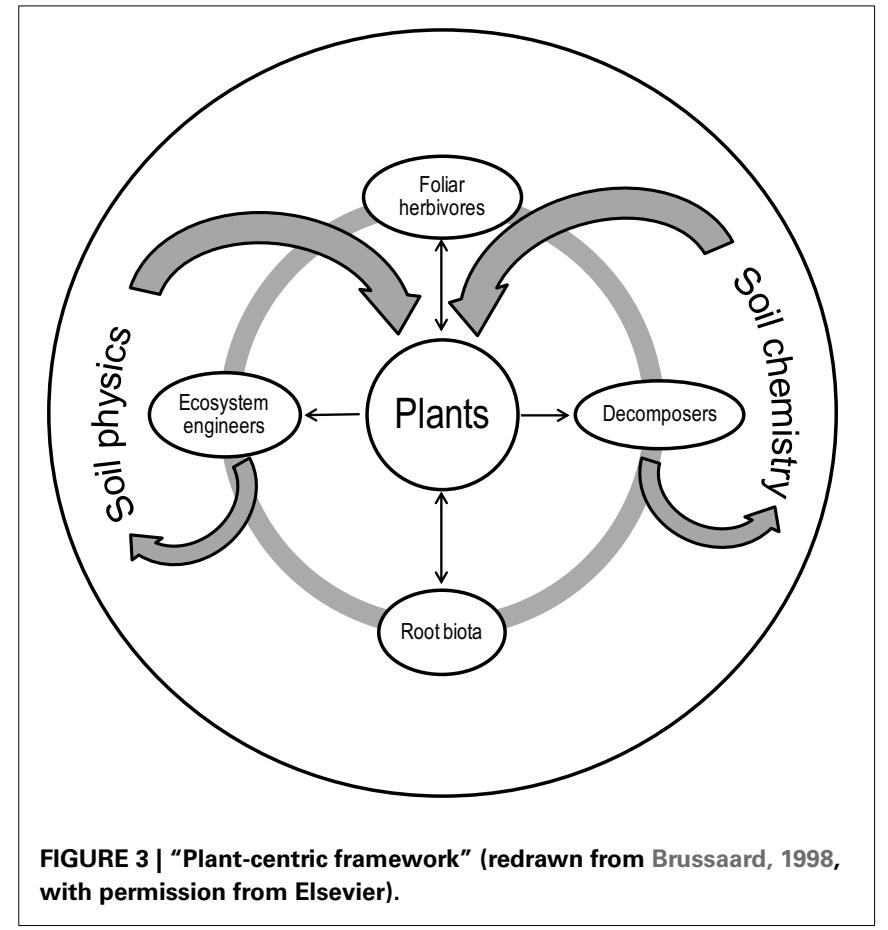

carbon to fungi in exchange for phosphorous and therefore, complementing each other (Bonkowski et al., 2001).

In view of all these important plant influences, Brussaard (1998) concluded that plants should take a central place in soil ecosystem functioning because they govern the role that soil fauna plays in soil processes. Therefore, in his model plants interact, directly or indirectly, with the physical and chemical environment and with three biotic components or "guilds" of soil organisms influencing decomposition processes: root herbivores (living in association with or feeding directly on roots), decomposers (microbiota and micro-/mesofauna occupying either the bulk soil or "hotspots" where they graze microorganisms or comminute the litter entering into the soil) and "bioturbators" or ecosystem engineers (meso-/macrofauna which create favorable environments for other colonizing organisms) (Figure 3). Each of these guilds could show some degree of resource partitioning, which allows coexistence, and for example, among that of root herbivores, different insect species can coexist by having different feeding niches, such as the root collar, central vascular tissue, root cortex or externally on the root (Brown and Gange, 1990). Species spatial aggregation is an influential factor of species coexistence and in turn, ecosystem processes (e.g., Freckleton and Watkinson, 2000; Stoll and Prati, 2001).

\section{FUTURE PERSPECTIVES TO ENABLE A MORE REALISTIC QUANTITATIVE EVALUATION OF SOIL FAUNA ROLES IN ECOSYSTEM FUNCTIONING}

Current "functional classifications" can only be considered as "major groups" connected to "major functions" (Lavelle, 2002) and therefore, there has been a claim to be more rigorous when applying their definition criteria (Brussaard et al., 1997). Although numbers and their weights and sizes are relatively easy 

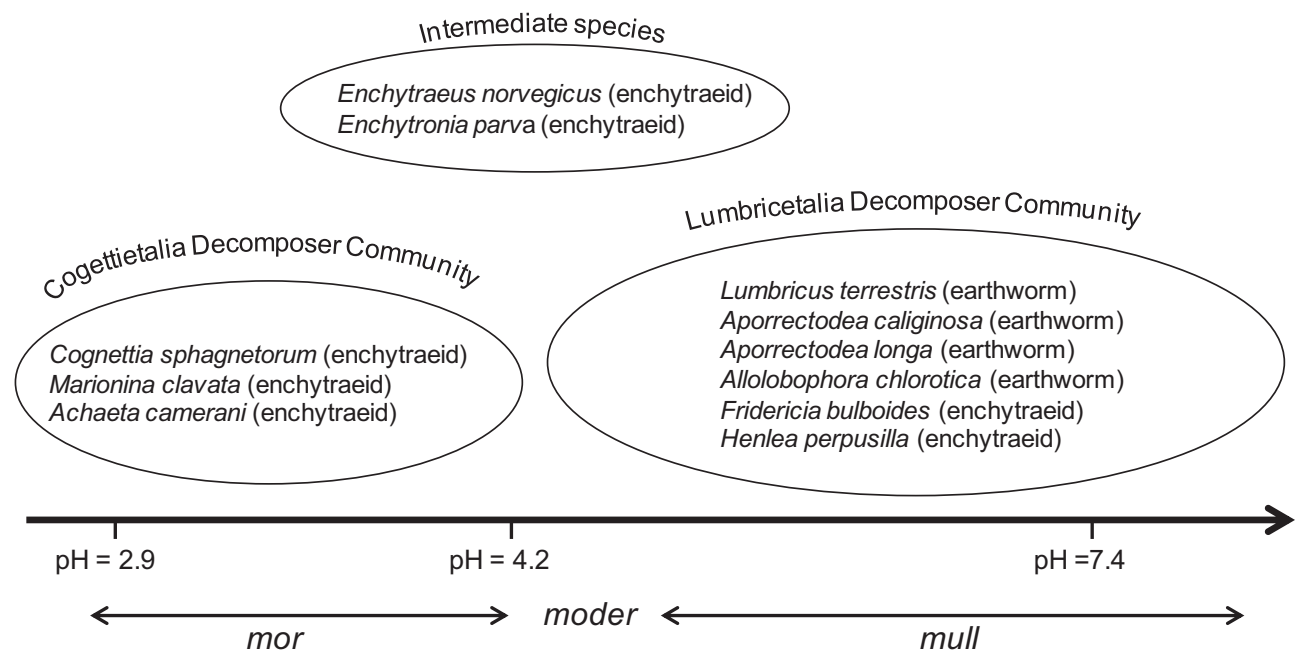

FIGURE 4 | Distribution of 4 earthworm and 5 enchytraeid species along a soil pH gradient (redrawn from Graefe and Beylich, 2003, with permission from Wageningen University).

to measure, quantifying the contribution of soil fauna to soil processes would require incorporating additional information on animal activities, their life styles, feeding habits, reproduction rates and reproductive strategies. In other words, defining "functional groups" would not only imply assigning specific functions to certain taxa (or mixed groups), but also integrating the physical, chemical and climatic environment of the soil with the interactive activities of the organisms living in it (both above- and below-ground). More specifically, a further refinement of soil faunal functional classifications will involve including the following aspects:

(i) Because these groupings are aggregated units whose definition is associated with some degree of arbitrariness (Bengtsson, 1998) and they include a variable number of taxa, the definition of a functional group with respect to one particular function might not fit with respect to another.

(ii) Some groups are associated with more than one function; therefore, we should be changing the focus from "organismcentered" to "processes-centered" (Hodkinson and Wookey, 1999).

(iii) Their functional activities could be temporally and spatially separated and different groups could act at different stages of a particular process (e.g., decomposition) or at different depths along the soil profile (Clapp et al., 1995).

(iv) Some organisms can perform different functions during their life cycle (Lavelle, 1996). In addition, immature stages (juveniles, larvae) could be dominant in numbers in particular habitats or in specific seasons (Vineesh et al., 2007), and have different feeding requirements, different assimilation efficiencies and egesting rates from their adults (Luxton, 1972).

(v) Many soil processes are intimately coupled: for example, SOM decomposition, nutrient cycling and primary productivity. (vi) "Sanitation" effects (sensu Van der Drift, 1965) resulting, for example, from mites feeding on antibiotic-producing fungi (Luxton, 1972) could favor other microorganisms to grow. Similarly, selective consumption of pathogenic fungi by earthworms could enhance or reduce their incidence (Moody et al., 1995).

(vii) Soil characteristics (e.g., soil texture, moisture conditions, $\mathrm{pH}$ ) could alter the hierarchical role of soil biota on soil processes. For example, in sandy soils endogeic earthworms play a major role in soil structure formation and maintenance, whereas in clayed soils the earthworms had a secondary role and the effect of roots and organic materials becomes predominant (Blanchart et al., 1999). Similarly, the effects of microarthropod communities on $\mathrm{N}$ mineralization appear to be greater under drier conditions (Persson, 1989), possibly due to the regulating effect they exert on enchytraeid populations which does not operate at higher moisture contents (Huhta et al., 1998).

The influence of soil $\mathrm{pH}$ on shaping soil biota communities is best exemplified by Graefe and Beylich (2003), who established a threshold value of $4.2\left(\mathrm{pH} \mathrm{CaCl}_{2}\right)$ below which, these communities completely change their species composition and functionality, resulting in the development of different types of humus in soils (Figure 4). This could explain why in mineral soils macrofauna and earthworms, in particular, are expected to be the key faunal component, whereas in organic rich soils other smaller sized organisms (e.g., oribatid mites and enchytraeids) may play a more determinant role in soil processes (e.g., Luxton, 1972; Laakso and Setälä, 1999). Following this, liming, a common practice to raise soil $\mathrm{pH}$ in arable soils, is expected to benefit SOM turnover and nutrient cycling; however, this is not always the case and for example, Gray et al. (2003) found that, despite of increasing plant productivity and changing soil biota composition, liming did not have any detectable effect on soil respiration. This 


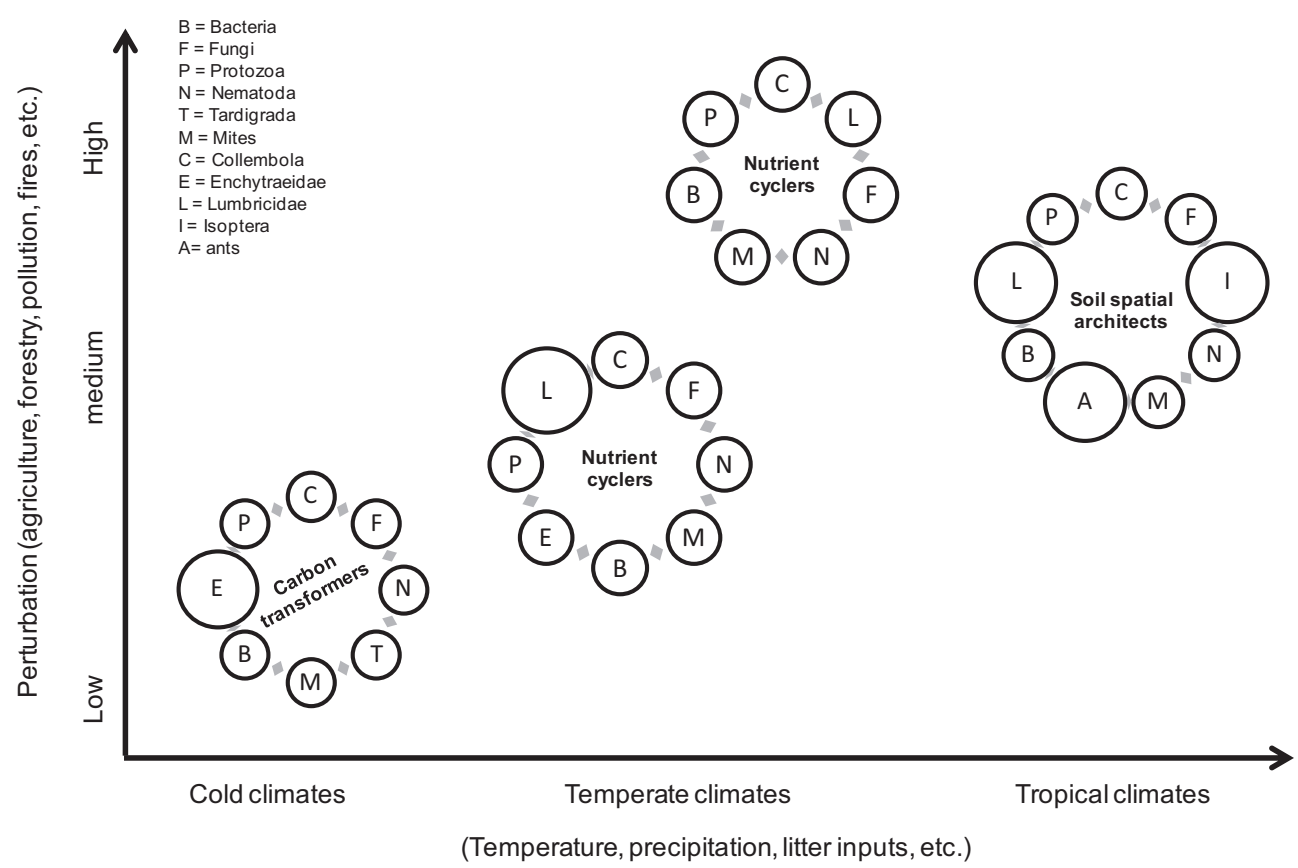

FIGURE 5 | Hypothetical changes in functional assemblages across three different biomes.

discrepancy was explained as a result of soil $\mathrm{pH}$ not increasing beyond the turning point of 4.2 when lime is applied to mineral soils, which favors intermediate species (Figure 4; Graefe and Beylich, 2003).

(viii) Another issue that should be considered is whether the results obtained for any given soil process in a given ecosystem could be extrapolated to another process and ecosystem (Loreau et al., 2001). For example, in temperate grasslands above-ground processes (e.g., primary production and nutrient retention) appear to be under direct plant control and it does not seem to be linked to below-ground processes (e.g., SOM turnover and nutrient cycling) which are under microbial control.

(ix) Because climate, which operates at large scales of time and space, is the main factor determining soil fauna contribution to soil processes at global scale (Swift et al., 1979; Lavelle et al., 1993), functional classifications could be structured in a different way in different biomes. Lavelle et al. (1997) give some interesting examples of disappearance and functional substitution of different soil animal groups in response to latitudinal changes: (i) high acidity and waterlogging conditions which prevent ecosystem engineers to succeed can result in other invertebrates (isopods and coleopterans, gastropods, diplopods, centipedes, dipteral larvae, and enchytraeids) assuming similar, although limited, roles; (ii) earthworms tend to be better represented in grasslands situated in humid areas than in forested and dry areas, whereas litter arthropods seem to be predominant in ecosystems where sufficient litter is available; (iii) in cold and temperate climates earthworms feed on more organic material and the proportion of endogeic worms is lower, whereas warmer climates are likely to change earthworm communities with a relative increase of endogeic populations and hence, higher activity in the deeper layers; (iv) in tropical soils there seems to exist an inverse relationship between earthworms and termites, with dominance of termites during the dry seasons and earthworms during the wet ones.

Therefore, as highlighted by Lavelle (1996) there is a need for functional classifications that: (1) group redundant species, (2) are based on well identified functions in soils, (3) give prominent status to species or groups with key functions, but (4) recognize that some groups that do not significantly affect the rates of any ecosystem process may serve as indicators of ongoing processes. This represents a major scientific challenge which will require a great number of multidisciplinary scientific efforts.

Among possible solutions to achieve this enormous task, it has been suggested to adopt a continuous approach, in which a set of relevant biological traits are used as predictors of their function in soil (Hedde et al., 2005). This recalls the distinction made by Hodgson et al. (1999) between "soft biological traits," easy to measure, but not directly related to a specific functional mechanism (e.g., size, growth form, maturation age, life span, etc.) and "hard biological traits," difficult (or impossible) to measure but having direct functional role (e.g., growth rate in response to environmental factors, ecosystem engineers biostructures).

Another alternative approach is to categorize each functional group according to its relative position along several axes determining species' interactions with the abiotic and biotic environment. For example, Hodkinson and Wookey (1999) proposed four axes: population responsiveness (i.e., the speed and magnitude of the response to changing conditions to maintain its 
position within the community: life cycles, $\mathrm{K}$ and $\mathrm{r}$ strategies, generation times), dispersability (horizontal dispersal and colonization abilities), ecophysiological flexibility (stress tolerance, growth and survival strategies) and resource use flexibility (ability to cope with spatial and temporal variations in resource availability).

Because species respond to climate, edaphic factors, resource quality and availability from the primary produces and perturbations, integrated knowledge is needed. At the same time, unidirectional causality approaches, in which diversity is either a cause or an effect, should be avoided and the focus should be placed on finding interactive relationships and feedbacks among biodiversity and environmental changes and ecosystem functioning (Loreau et al., 2001). In addition, diversity, ecosystem properties and environmental conditions should be better viewed as dynamic variables (Hooper et al., 2005), in terms of their responses and influences on soil processes.

New mathematical techniques are emerging, such as the "competitivity graph," developed by Criado et al. (2013) to compare the competitiveness of a family of rankings. Although competition does not appear to have a strong influence on below-ground communities (Wardle, 2002; Bardgett et al., 2005; Decaëns, 2010), one may assume that biomes/ecosystems are dynamic systems in which different functional assemblages compete for resources leading to competitive ranks, so that the functional contribution of a particular keystone species or functional group to a given soil process is more pivotal than that of the remaining soil organisms (hierarchy). The number of interactive players and the relevance of a particular group as a "ruling player" or a "ruling team" (e.g., plants, litter fragmenters, ecosystem engineers) would be subjected to changes in climatic, edaphic conditions and to perturbation (e.g., agricultural practices, fires, pollution) operating in those systems and hence, the magnitude and direction of the regulated soil function. But, even in the absence of perturbation, these rankings could change with season and nutrient inputs (via plants) and therefore, the "dynamic" model is superimposed to the hierarchical model.

One illustrative example is shown in Figure 5 in which a hypothetical change in functional structure of soil biota across three different biomes and different degrees of perturbation, together with their main contributing roles, are depicted. Because the factors that shape biomes (prevailing climate) also drive functional composition of plants and soil organisms, it could be hypothesized that one axis of functional variation could be represented by the correlation between environmental and biotic factors and the geographical spatial patterns, whereas any parameter altering both the ecological and physiological responses and reproduction and dispersability rates of biota could conform one or more perturbation axes (i.e., a "multidimensional" approach). Therefore, for example, in cold climates (Figure 5), where environmental conditions restrict the presence of macrofauna and the $\mathrm{C}$ storage function dominates, enchytraeids become the pivotal organisms in performing soil mixing and $\mathrm{C}$ transformations (i.e., they are "C-transformers"). Although, these small sized-worms have been traditionally classified as "litter transformers" (Lavelle, 1996), at least in $\mathrm{C}$ rich soils, their bioturbating (which increase hydraulic conductivity and hence nutrient leaching) and casts activities (which are hotspots for microbial activities, etc.) would entitle them to be considered the "ecosystem engineers of the organic layers."

Under milder climatic conditions (e.g., temperate and tropical climates), ecosystem engineers (or "soil architects," if we accept that enchytraeids, and possibly other biota are also engineers) take over mesofauna's role and become the key players in the mineralization of the SOM (Figure 5). However, if the system is perturbed (e.g., land use change), their functional contribution could be either greatly reduced (e.g., as a result of higher mortality rates within a specific feeding or ecological group) or completely missed (e.g., as a result of heavy use of pesticides and herbicides). The outcome of those species/groups' losses will depend on the functional abilities of the remaining players (which could change their role from functionally redundant to functionally active) and the duration of the perturbation (i.e., resistance or resilience).

This conceptual scheme could also be useful for studying intraand inter-annual differences in the functional assemblages and whether, at any particular time, the interactions among a selective number of players are stronger than those occurring in a different season. At smaller scale, it could also be possible to investigate whether these groupings change with microhabitat stratification or under different plant species and, in this case, the axes of variation would be specific soil properties and plant traits.

This new overview agrees with the conclusions from the work by Hodkinson and Wookey (1999), who indicated that, at least for Arctic ecosystems, the community resilience to environmental changes largely depends on the long term fluctuations in environmental factors (which provides the "environmental inertia" and "biotic inertia") and on the short term environmental variation [which provides "amplitude" (ecosystem stress tolerance) and "elasticity" (speed to return to the equilibrium state)].

Biological evolution is full of examples of over-specialization as well as wasteful structures; perhaps, the huge diversity present in soils allows "biotic plasticity" and its practical value will only become evident under different circumstances and this, itself, represents a good reason to preserve it. In a near future we will need to know the extent of this property to be able to determine the minimum number of species to produce an ecosystem good, to maintain an ecosystem function or to mitigate climate change.

\section{ACKNOWLEDGMENTS}

I would like to thank Mrs. J. Coward (librarian at CEH Lancaster, UK) for providing some of the articles used in this review and to Dr. F. Ramil (Universidad de Vigo, Spain) for helping with the German translation of some of these papers. I gratefully acknowledge the valuable information provided by Dr. P. Eggleton (Natural History Museum, London, UK) and Dr. C. Gómez (Universidad de Gerona, Spain) regarding the functional classifications of termites and ants, respectively.

\section{REFERENCES}

Abe, T. (1987). "Evolution of life types in termites," in Evolution and Coadaptation in Biotic Communities, eds S. Kawano, J. H. Connell, and T. Hidaka (Tokyo: University of Tokyo Press), 125-148.

Abrahamsen, G. (1973). Studies on body-volume, body-surface area, density and live weight on Enchytraeidae (Oligochaeta). Pedobiologia 13, 6-15. 
Addison, J. A., Trofymow, J. A., and Marshall, V. G. (2003). Functional role of Collembola in succesional coastal temperate forests on Vancouver Island, Canada. Appl. Soil Ecol. 24, 247-261. doi: 10.1016/S0929-1393(03)00089-1

Andersen, A. N. (1990). The use of ant communities to evaluate change in Australian terrestrial ecosystems: a review and a recipe. Proc. Ecol. Soc. Aust. 16, 347-357.

Andersen, A. N. (1995). A classification of Australian ant communities, based on functional-groups which parallel plant life-forms in relation to stress and disturbance. J. Biogeogr. 22, 15-29. doi: 10.2307/2846070

Andersen, A. N. (1997). Functional groups and patterns of organization in North American ant communities: a comparison with Australia. J. Biogeogr. 24, 433-460. doi: 10.1111/j.1365-2699.1997.00137.x

Andersen, A. N. (2000). "A global ecology of rainforest ants: functional groups in relation to environmental stress and disturbance. Chapter 3," in Standard Methods for Measuring and Monitoring Biodiversity, eds D. Agosti, J. D. Majer, L. Alonso, and R. Schultz (Washington, DC: Smithsonian Institution Press), 25-34.

Anderson, J. M. (1988). Spatio-temporal effects of invertebrates on soil processes. Biol. Fert. Soils 6, 216-227. doi: 10.1007/BF00260818

André, H. M., Noti, M. I., and Lebrun, P. (1994). The soil fauna: the other last biotic frontier. Biodivers. Conserv. 3, 45-56. doi: 10.1007/BF00115332

Andrén, O., and Balandreau, J. (1999). Biodiversity and soil functioning-from black box to can of worms? Appl. Soil Ecol. 13, 105-108. doi: 10.1016/S09291393(99)00025-6

Andrén, O., Bengtsson, J., and Clarholm, M. (1995). "Biodiversity and species redundancy among litter decomposers," in The Significance and Regulation of Biodiversity, eds H. P. Collins, G. P. Robertson, and M. J. Klug (Dordrecht: Kluwer), 141-151.

Andrén, O., Brussaard, L., and Clarholm, M. (1999). Soil organism influence on ecosystem-level processes-bypassing the ecological hierarchy? Appl. Soil Ecol. 11, 177-188, doi: 10.1016/S0929-1393(98)00144-9

Bardgett, R. D. (2002). Causes and consequences of biological diversity in soil. Zoology 105, 367-374. doi: 10.1078/0944-2006-00072

Bardgett, R. D., Yeates, G. W., and Anderson, J. M. (2005). "Patterns and determinants of soil biological diversity," in Biological Diversity and Function in Soils, eds R. D. Bardgett, M. B. Usher, and D. W. Hopkins (Cambridge: Cambridge University Press), 100-118. doi: 10.1017/CBO9780511541926.007

Bengtsson, J. (1998). Which species? What kind of diversity? Which ecosystem function? Some problems in studies of relations between biodiversity and ecosystem function. Appl. Soil Ecol. 10, 191-199. doi: 10.1016/S09291393(98)00120-6

Bengtsson, J., Setälä, H., and Zheng, D. W. (1995). "Food webs and nutrient cycling in soils: interactions and positive feedbacks," in Food Webs: Pattern and Processes, eds G. Polis and K. Winemiler (London: Chapman and Hall), 30-38.

Berke, S. K. (2010). Functional groups of ecosystem engineers: a proposed classification with comments current issues. Integr. Comp. Biol. 50, 147-157. doi: 10.1093/icb/icq077

Blanchart, E., Albrecht, A., Alegre, J., Duboisset, A., Gilot, C., Pashanasi, B., et al. (1999). "Effects of earthworms on soil structure and physical properties," in Earthworm Management in Tropical Agroecosystems, eds P. Lavelle, L. Brussaard, and P. Hendrix (Wallingford, WA: CAB International), 149-172.

Blüthgen, N., Gebauer, G., and Fiedler, K. (2003). Disentagling a rainforest foodweb using stable isotopes: dietary diversity in a species-rich ant community. Oecologia 137, 426-435. doi: 10.1007/s00442-003-1347-8

Bongers, T., and Bongers, M. (1998). Functional diversity of nematodes. Appl. Soil Ecol. 10, 239-251. doi: 10.1016/S0929-1393(98)00123-1

Bonkowski, M., Jentsche, G., and Scheu, S. (2001). Contrasting interests in the rhizosphere: interactions between Norway spruce seedlings (Picea abies Karst.), mycorrhiza (Paxillus involutus (Bartsch) Fr.) and naked amoeba (Protozoa). Appl. Soil Ecol. 18, 193-204. doi: 10.1016/S0929-1393(01) 00165-2

Bonkowski, M., and Schaefer, M. (1997). Interactions between earthworms and soil Protozoa: a trophic component in the soil food-web. Soil Biol. Biochem. 29, 499-502. doi: 10.1016/S0038-0717(96)00107-1

Bonkowski, M., Scheu, S., and Schaefer, M. (1998). Interactions of earthworms (Octolasion lacteum), millipedes (Glomeris marginata) and plants (Hordelymus europeaus) in a beechwood on a basalt hill: implications for litter decomposition and soil formation. Appl. Soil Ecol. 9, 161-166. doi: 10.1016/S0929-1393(98)00070-5

Bouché, M. B. (1977). "Stratégies lombriciennes," in Soil Organisms as Components of Ecosystems, eds U. Lohm and T. Persson (Stockholm: Ecological Bulletin vol. 25), 122-132.

Boxshall, G. A., and Self, D. (2011). UK Taxonomy and Systematics Review-2010. Natural Environment Research Council. Available online at: http://www.nerc.ac. uk/research/programmes/taxonomy/documents/uk-review.pdf

Bradford, M. A., Tordoff, G. M., Black, H. I. J., Cook, R., Eggers, T., Garnett, M. H., et al. (2007). Carbon dynamics in a model grassland with functionally different soil communities. Funct. Ecol. 21, 690-697. doi: 10.1111/j.13652435.2007.01268.x

Briones, M. J. I., and Ineson, P. (2002). Use of ${ }^{14} \mathrm{C}$ carbon dating to determine feeding behaviour of enchytraeids. Soil Biol. Biochem. 34, 881-884. doi: 10.1016/S0038-0717(02)00010-X

Briones, M. J. I., Ineson, P., and Piearce, T. G. (1997). Effects of climate change on soil fauna; responses of enchytraeids, Diptera larvae and tardigrades in a transplant experiment. Appl. Soil Ecol. 6, 117-134. doi: 10.1016/S09291393(97)00004-8

Briones, M. J. I., Ineson, P., and Sleep, D. (1999). Use of $\delta^{13} \mathrm{C}$ values to determine food selection in collembolan species. Soil Biol. Biochem. 31, 937-940. doi: 10.1016/S0038-0717(98)00179-5

Briones, M. J. I., Moran, P., and Posada, D. (2009). Are the sexual, somatic and genetic characters enough to solve nomenclatural problems in lumbricid taxonomy? Soil Biol. Biochem. 41, 2257-2271. doi: 10.1016/j.soilbio.2009 07.008

Briones, M. J. I., and Schmidt, O. (2004). "Stable isotope techniques in studies of the ecological diversity and functions of earthworm communities in agricultural soils," in Recent Research Developments in Crop Science, Vol. 1, ed S. G. Pandalai (Trivandrum: Research Signpost).

Brown, V. K., and Gange, A. C. (1990). Insect herbivory below ground. Adv. Ecol. Res. 20, 1-58. doi: 10.1016/S0065-2504(08)60052-5

Brown, W. L. Jr. (2000). "Diversity of Ants. Chapter 5," in Standard Methods for Measuring and Monitoring Biodiversity, eds D. Agosti, J. D. Majer, L. Alonso, and R. Schultz (Washington, DC: Smithsonian Institution Press), 45-79.

Brussaard, L. (1998). Soil fauna, guilds, functional groups and ecosystem processes. Appl. Soil Ecol. 9, 123-135. doi: 10.1016/S0929-1393(98)00066-3

Brussaard, L., Behan-Pelletier, V., Bignell, D., Brown, V., Didden, W., Folgarait, P., et al. (1997). Biodiversity and Ecosystem functioning in Soil. Ambio 26, 563-570.

Burtelow, A., Bohlen, P. J., and Groffmann, P. M. (1998). Influence of exotic earthworm invasion on soil organic matter, microbial biomass and denitrification potential in forest soils of the northeastern US. Appl. Soil Ecol. 9, 197-202. doi: 10.1016/S0929-1393(98)00075-4

Chamberlain, P. M., Bull, I. D., Black, H. I. J., Ineson, P., and Evershed, R. P. (2005). Fatty acid composition and change in Collembola fed differing diets: identification of trophic biomarkers. Soil Biol. Biochem. 37, 1608-1624. doi: 10.1016/j.soilbio.2005.01.022

Chamberlain, P. M., Bull, I. D., Black, H. I. J., Ineson, P., and Evershed, R. P. (2006). Collembolan trophic preferences determined using fatty acid distributions and compound-specific stable carbon isotope values. Soil Biol. Biochem. 38, 1275-1281. doi: 10.1016/j.soilbio.2005.09.022

Chang, C. H., Rougerie, R., and Chen, J. H. (2009). Identifying earthworms through DNA barcodes: pitfalls and promise. Pedobiologia 52, 171-180. doi: 10.1016/j.pedobi.2008.08.002

Chauvel, A., Grimaldi, M., Barros, E., Blanchart, E., Desjardins, T., Sarrazin, M., et al. (1999). Pasture damage by an Amazonnian earthworm. Nature 398, 32-33. doi: $10.1038 / 17946$

Chesson, P., Pacala, S., and Neuhauser, C. (2002). "Environmental niches and ecosystem functioning," in Functional Consequences of Biodiversity: Experimental Progress and Theoretical Extensions, eds A. Kinzig, D. Tilman, and S. Pacala (Priceton, NJ: Princeton University Press), 213-245.

Clapp, J. P., Young, J. P. W., Merryweather, J. W., and Fitter, A. H. (1995). Diversity of fungal symbionts in arbuscular mycorrhizas from a natural community. New Phytol. 130, 259-265. doi: 10.1111/j.1469-8137.1995.tb03047.x

Cole, L., Dromph, K. M., Boaglio, V., and Bardgett, R. D. (2004). Effect of density and species richness of soil mesofauna on nutrient mineralization and plant growth. Biol. Fert. Soils 39, 337-343. doi: 10.1007/s00374-0030702-6 
Coomans, A. (2002). Present status and future of nematode systematics. Nematology 4, 573-582. doi: 10.1163/15685410260438836

Copley, J. (2000). Ecology goes underground. Nature 406, 452-454. doi: $10.1038 / 35020131$

Cortet, J., Joffre, R., Elmholt, S., and Krogh, P. H. (2002). Increasing species and throphic diversity of mesofauna affects fungal biomass, mesofauna community structure and organic matter decomposition processes. Biol. Fert. Soils 37 , 302-317. doi: 10.1007/s00374-003-0597-2

Costello, M. J., May, R. M., and Stork, N. E. (2013). Can we name Earth's species before they go extinct? Science 339, 413-416. doi: 10.1126/science.1230318

Coûteaux, M. M., and Darbyshire, J. F. (1998). Functional diversity amongst soil protozoa. Appl. Soil Ecol. 10, 229-237. doi: 10.1016/S0929-1393(98) 00122-X

Criado, R., García, E., Pedroche, F., and Romance, M. (2013). A new method for comparing rankings through complex networks: model and analysis of competitiveness of major European soccer leagues. Chaos 23, 043114. doi: $10.1063 / 1.4826446$

Cuddington, K., Wilson, W. G., and Hastings, A. (2009). Ecosystem engineers: feedback and population dynamics. Am. Nat. 173, 488-498. doi: 10.1086/597216

Cummins, K. W. (1974). Structure and function of stream ecosystems. Bioscience 24, 631-641. doi: 10.2307/1296676

Davidson, D. A., Bruneau, P. M. C., Grieve, I. C., and Young, I. M. (2002). Impacts of fauna on an upland grassland soil as determined by micromorphological analysis. Appl. Soil Ecol. 20, 133-143. doi: 10.1016/S0929-1393(02) 00017-3

Dawkins, R. (1982). "The genetical evolution of animal artefacts," in The Extended Phenotype: The Long Reach of a Gene (New York, NY: Oxford University Press), 195-208.

De Deyn, G. B., and Van der Putten, W. H. (2005). Linking aboveground and belowground diversity. Trends Ecol. Evol. 20, 625-633. doi: 10.1016/j.tree.2005.08.009

De Ruiter, P. C., Moore, J. C., Zwart, K. B., Bouwman, L. A., Hassink, J., Bloem, J., et al. (1993). Stimulation of nitrogen mineralisation in the below-ground food webs of two winter wheat fields. J. Appl. Ecol. 30, 95-106. doi: 10.2307/ 2404274

De Ruiter, P. C., Neutel, A.-M., and Moore, J. C. (1995). Energetics, patterns of interaction strengths and stability in real ecosystems. Science 269, 1257-1260. doi: $10.1126 /$ science.269.5228.1257

Decaëns, T. (2010). Macroecological patterns in soil communities. Global Ecol. Biogeogr. 19, 287-302. doi: 10.1111/j.1466-8238.2009.00517.x

Decaëns, T., Jiménez, J. J., Gioia, C., Measey, G. J., and Lavelle, P. (2006). The values of soil animals for conservation biology. Eur. J. Soil Biol. 42, S23-S38. doi: 10.1016/j.ejsobi.2006.07.001

Decaëns, T., Lavelle, P., and Jiménez, J. J. (2008). Priorities for conservation of soil animals. CAB Rev. Perspect. Agric. Veterin. Sci. Nutr. Nat. Resour. 3:14. doi: 10.1079/PAVSNNR20083014

Detsis, V. (2000). Vertical distribution of Collembola in deciduous forests under Mediterranean climatic conditions. Belg. J. Zool. 130(Suppl.), 55-59. Available online at: http://www.naturalsciences.be/institute/associations/ rbzs_website/pdf/abstracts_130_s1/130_s1_9.pdf

Donovan, S. E., Eggleton, P., and Bignell, D. E. (2001). Gut content analysis and a new feeding group classification of termites. Ecol. Entomol. 26, 356-366. doi 10.1046/j.1365-2311.2001.00342.x

Eggleton, P., and Tayasu, I. (2001). Feeding groups, lifetypes and the global ecology of termites. Ecol. Res. 16, 941-960. doi: 10.1046/j.1440-1703.2001.00444.x

Emerson, B. C., Cicconardi, F., Fanciulli, P. P., and Shaw, P. J. (2011). Phylogeny, phylogeography, phylobetadiversity and the molecular analysis of biological communities. Philos. Trans. R. Soc. Lond. B Biol. Sci. 366, 2391-2402. doi: 10.1098/rstb.2011.0057

Faber, J. H. (1991). Functional classification of soil fauna: a new approach. Oikos 62, 110-117. doi: $10.2307 / 3545458$

Faber, J. H., and Verhoef, H. A. (1991). Functional differences between closelyrelated soil arthropods with respect to decomposition processes in the presence or absence of pine tree roots. Soil Biol. Biochem. 23, 15-23. doi: 10.1016/00380717(91)90157-F

Ferris, H. (1982). "The role of nematodes as primary consumers," in Nematodes in Soil Ecosystems, ed D. W. Freckman (Austin, TX: University of Texas Press), $3-13$.

Fierer, N., Leff, J. W., Adams, B. J., Nielsen, U. N., Bates, S. T., Lauber, C. L., et al. (2012). Cross-biome metagenomic analyses of soil microbial communities and their functional attributes. Proc. Natl. Acad. Sci. U.S.A. 109, 21390-21395. doi: $10.1073 /$ pnas. 1215210110

Filser, J. (2003). The role of Collembola in carbon and nitrogen cycling in soil. Pedobiologia 46, 234-245. doi: 10.1078/0031-4056-00130

Fitter, A. H., Gilligan, C. A., Hollingworth, K., Kleczkowski, A., Twyman, R. M., Pitchford, J. W., et al. (2005). Biodiversity and ecosystem function in soil. Funct. Ecol. 19, 369-377. doi: 10.1111/j.0269-8463.2005 00969.x

Folgarait, P. (1998). Ant biodiversity and its relationship to ecosystem functioning: a review. Biodivers. Conserv. 7, 1221-1244. doi: 10.1023/A:1008891901953

Folke, C., Holling, C. S., and Perrings, C. (1996). Biological biodiversity, ecosystems and the human scale. Ecol. Appl. 6, 1018-1024. doi: 10.2307/2269584

Freckleton, R. P., and Watkinson, A. R. (2000). On detecting and measuring competition in spatially structured plant communities. Ecol. Lett. 3, 423-432. doi: 10.1046/j.1461-0248.2000.00167.x

Freckman, D. W., Blackburn, T. H., Brussaard, L., Hutchings, P., Palmer, M. A., and Snelgrove, P. V. R. (1997). Linking biodiversity and ecosystem functioning of soil and sediments. Ambio 26, 556-562.

Gibb, H., and Cunningham, S. A. (2011). Habitat contrasts reveal a shift in the trophic position of ant assemblages. J. Anim. Ecol. 80, 119-127. doi: 10.1111/j.1365-2656.2010.01747.x

Gisin, H. (1943). Ökologie und Lebensgemeinschaften der Collemolen im Schweizerischen Exkursionsgebiet Basels. Rev. Suisse Zool. 50, 183-189.

Gómez, C., Casellas, D., Oliveras, J., and Bas, J. M. (2003). Structure of groundforaging ant assemblages in relation to land-use change in the northwestern Mediterranean region. Biodivers. Conserv. 12, 2135-2146. doi: 10.1023/A:1024 142415454

Gorny, M. (1984). "Studies on the relationship between enchytraeids and earthworms," in Soil Biology and Conservation of the Biosphere, ed J. Szegi (Budapest: Academiai Kiado), 769-776.

Graefe, U., and Beylich, A. (2003). Critical values of soil acidification for annelid species and the decomposer community. Newslett. Enchytraeidae 8, 51-55. Available online at: http://www.ifab-hamburg.de/ documents/GraefeBeylich2003.pdf

Grassé, P. P. (1984). Termitologia. Paris: Masson.

Gray, N. D., Hastings, R. C., Sheppard, S. K., Loughnane, P., Lloyd, D., McCarthy, A. J., et al. (2003). Effects of soil improvement treatments on bacterial community structure and soil processes in an upland grassland soil. FEMS Microbiol. Ecol. 46, 11-22. doi: 10.1016/S0168-6496(03)00160-0

Greenslade, P. J. M., and Halliday, R. B. (1983). Colony dispersion and relationships of meat ants Iridomyrmex purpureus and allies in an arid locality in South Australia. Insect Soc. 30, 82-99. doi: 10.1007/ BF02225659

Hågvar, S. (1998). The relevance of the Rio Convention on biodiversity to conserving the biodiversity of soils. Appl. Soil Ecol. 9, 1-7. doi: 10.1016/S09291393(98)00115-2

Hartmann, A., Rothballer, M., and Schmid, M. (2008). Lorenz Hiltner, a pioneer in rhizosphere microbial ecology and soil bacteriology research. Plant Soil 312, 7-14. doi: 10.1007/s11104-007-9514-Z

Hawkins, C. P., and MacMahon, J. A. (1989). Guilds: the multiple meanings of a concept. Ann. Rev. Ent. 34, 423-451. doi: 10.1146/annurev.en.34.010189.002231

Hawksworth, D. L., and Mound, L. A. (1991). "Biodiversity databases: the crucial significance of collections," in The Biodiversity of Microorganisms and Invertebrates: Its Role in Sustainable Agriculture, ed D. L. Hawksworth (Wallingford, WA: CAB International), 17-31.

Hedde, M., Lavelle, P., Joffre, R., Jimenez, J. J., and Decaëns, T. (2005). Specific functional signature in soil-macroinvertebrate biostructures. Funct. Ecol. 19, 785-793. doi: 10.1111/j.1365-2435.2005.01026.x

Heemsbergen, D. A., Berg, M. P., Loreau, M., van Hal, J. R., Faber, J. H., and Verhoef, H. A. (2004). Biodiversity effects on soil processes explained by interspecific functional dissimilarity. Science 306, 1019-1020. doi: 10.1126/science. 1101865

Heisler, C. L., Wickenbrock, L., and Lübben, H. (1996), Oberflächenstruktur, Aggregatstabilität sowie Durchwurzelbarkeit des Bodens unter dem Einfluss ausgewählter Bodentiergruppen. Z. Ökol. Natursch. 5, 97-105.

Hiltner, L. (1904). Ueber neuere Erfahrungen und Probleme auf dem Gebiete der Bodenbakteriologie und unter besonderer BerUcksichtigung der Grundungung und Brache. Arbeiten der Deutsche Landwirtschafts-Gesellschaft 98, 59-78. 
Hodgson, J. G., Wilson, P. J., Hunt, R., Grime, J. P., and Thompson, K. (1999) Allocating C-S-R plant functional types: a soft approach to a hard problem. Oikos 85, 282-294. doi: 10.2307/3546494

Hodkinson, I. D., and Wookey, P. A. (1999). Functional ecology of soil organisms in tundra ecosystems: towards the future. Appl. Soil Ecol. 11, 111-126. doi: 10.1016/S0929-1393(98)00142-5

Hooper, D. U., Chapin, F. S. III., Ewel, J. J, Hector, A., Inchausti, P., Lavorel, S., et al. (2005). Effects of biodiversity on ecosystem functioning: a consensus of current knowledge. Ecol. Monogr. 75, 3-35. doi: 10.1890/04-0922

Hooper, D. U., and Dukes, J. S. (2004). Overyielding among plant functional groups in a long-term experiment. Ecol. Lett. 7, 95-105. doi: 10.1046/j.14610248.2003.00555.x

Hooper, D., Hawksworth, D., and Dhillion, S. (1995). "Microbial diversity and ecosystem processes," in Global Biodiversity Assessment, ed United Nations Environment Programme (Cambridge: Cambridge University Press), 433-443.

Huang, J., Xu, Q., Sun, Z. J., Tang, G. L., and Su, Z. Y. (2007). Identifying earthworms through DNA barcodes. Pedobiologia 51, 301-309. doi: 10.1016/j.pedobi.2007.05.003

Huhta, V. (2007). The role of soil fauna in ecosystems: a historical review. Pedobiologia 50, 489-495. doi: 10.1016/j.pedobi.2006.08.006

Huhta, V., Hyvönen, R., Kaasalainen, P., Koskenniemi, A., Muona, J., Mäkelä, I. et al. (1986). Soil fauna of Finnish coniferous forests. Ann. Zool. Fenn. 23 345-360.

Huhta, V., Sulkava, P., and Viberg, K. (1998). Interactions between enchytraeid (Cognettia sphagnetorum), microarthropod and nematode populations in forest soil at different moistures. App. Soil Ecol. 9, 53-58. doi: 10.1016/S09291393(98)00053-5

Hunt, H. W., Coleman, D. C., Ingham, E. R., Ingham, R. E., Elliott, E. T., Moore, J C., et al. (1987). The detrital foodweb in a shortgrass prairie. Biol. Fertil. Soils 3 $57-68$

Jones, C. G., Lawton, J. H., and Shachak, M. (1994). Organisms as ecosystem engineers. Oikos 69, 373-386. doi: 10.2307/3545850

Jones, C. G., Lawton, J. H., and Shachak, M. (1997). Positive and negative effects of organisms as physical ecosystem engineers. Ecology 78, 1946-1957. doi: 10.1890/0012-9658(1997)078[1946:PANEOO]2.0.CO;2

Jouquet, P., Dauber, J., Lagerlöf, J., Lavelle, P., and Lepage, M. (2006). Soil invertebrates as ecosystem engineers: intended accidental effects on soil and feedback loops. Appl. Soil Ecol. 32, 153-164. doi: 10.1016/j.apsoil.2005.07.004

Keudel, M., and Schrader, S. (1999). Axial and radial pressure exerted by earthworms of different ecological groups. Biol. Fert. Soils 29, 262-269. doi $10.1007 / \mathrm{s} 003740050551$

Kibblewhite, M. G., Ritz, K., and Swift, M. J. (2008). Soil health in agricultural systems. Philos. Trans. R. Soc. Lond. B Biol. Sci. 363, 685-701. doi: 10.1098/rstb.2007.2178

King, R. A., Tibble, A. L., and Symondson, W. O. C. (2008). Opening a can of worms: unprecedented sympatric cryptic diversity within British lumbricid earthworms. Mol. Ecol. 17, 4684-4698. doi: 10.1111/j.1365-294X.2008. 03931.x

Krištůfek, V., Nováková, A., and Pižl, V. (2001). Coprophilous streptomycetes and fungi-food sources for enchytraeid worms (Enchytraeidae). Folia Microbiol. 46, 555-558. doi: 10.1007/BF02818002

Laakso, J., and Setälä, H. (1999). Sensitivity of primary production to changes in the architecture of below-ground food webs. Oikos 87, 57-64. doi: 10.2307/ 3546996

Lavelle, P. (1979) Relations entre types ecologiques et profiles demographiques chez les vers de terre de la savanne de Lamto (Cote d'Ivore). Rev. Ecol. Biol. Sol. 16 , 85-101.

Lavelle, P. (1983). “The structure of earthworm communities," in Earthworm Ecology: from Darwin to Vermiculture, ed J. E. Satchell (London: Chapman and Hall), 449-466. doi: 10.1007/978-94-009-5965-1_39

Lavelle, P. (1988). Earthworms and the soil system. Biol. Fert. Soils 6, 237-251. doi: 10.1007/BF00260820

Lavelle, P. (1996). Diversity of soil fauna and ecosystem function. Biol. Int. 33, 3-16.

Lavelle, P. (2002). Functional domains in soils. Ecol. Res. 17, 551-450. doi: 10.1046/j.1440-1703.2002.00509.x

Lavelle, P., Bignell, D., Lepage, M., Wolters, V., Roger, P., Ineson, P., et al. (1997). Soil function in a changing world: the role of invertebrate ecosystem engineers. Eur. J. Soil Biol. 33, 159-193.
Lavelle, P., Blanchart, E., Martin, A., Martin, S., Barois, I., Toutain, F., et al. (1993). A hierarchical model for decomposition in terrestrial ecosystems. Application to soils in the humid tropics. Biotropica 25, 130-150. doi: 10.2307/ 2389178

Liiri, M., Setälä, H., Jaimi, J., Pennanen, H., and Fritze, H. (2002). Soil processes are not influenced by the functional complexity of soil decomposer foodwebs under disturbance. Soil Biol. Biochem. 34, 1009-1020. doi: 10.1016/S00380717(02)00034-2

Loreau, M., Naeem, S., Inchausti, P., Bengtsson, J., Grime, J. P., Hector, A., et al. (2001). Biodiversity and ecosystem functioning: current knowledge and future challenges. Science 294, 804-808. doi: 10.1126/science.1064088

Luxton, M. (1972). Studies on the oribatid mites of a Danish beech-wood soil. I Nutritional biology. Pedobiologia 12, 434-463.

MacFadyen, A. (1963). "The contribution of the fauna to the total soil metabolism," in Soil Organisms, eds J. Doeksen and J. van der Drift (Amsterdam: North Holland Publishing Company), 3-17.

MacFadyen, A. (1964). Relations between mites and microorganisms and their significance in soil biology. Acarologia 6, 147-149.

Marichal, R., Martinez, A. F., Praxedes, C., Ruiz, D., Carvajal, A. F., Oszwald, J., et al. (2010). Invasion of Pontoscolex corethrurus (Glossoscolecidae, Oligochaeta) in landscapes of the Amazonian deforestation arc. Appl. Soil Ecol. 46, 443-449. doi: 10.1016/j.apsoil.2010.09.001

Marilley, L., and Aragno, M. (1999). Phylogenetic diversity of bacterial communities from different proximity to Lolium perenne and Trifolium repens roots. Appl. Soil Ecol. 13, 127-136. doi: 10.1016/S0929-1393(99)00028-1

Martinsson, S., and Erséus, C. (2014). Cryptic diversity in the well-studied terrestrial worm Cognettia sphagnetorum (Clitellata: Enchytraeidae). Pedobiologia 57, 27-35. doi: 10.1016/j.pedobi.2013.09.006

McCann, K. S. (2000). The diversity-stability debate. Nature 405, 228-233. doi: $10.1038 / 35012234$

Moody, S. A., Briones, M. J. I., Piearce, T. G., and Dighton, J. (1995). Selective consumption of decomposing wheat straw by earthworms. Soil Biol. Biochem. 27, 1209-1213. doi: 10.1016/0038-0717(95)00024-9

Moore, J. C., and De Ruiter, P. C. (1991). Temporal and spatial heterogeneity of trophic interactions within below-ground food webs. Agr. Ecosyst. Environ. 34, 371-397. doi: 10.1016/0167-8809(91)90122-E

Moore, J. C., Walter, D. E., and Hunt, H. W. (1998). Arthropod regulation of micromesobiota in belowground detrital food webs. Ann. Rev. Entomol. 33, 419-439. doi: 10.1146/annurev.en.33.010188.002223

Mulder, C. (2006). Driving forces from soil invertebrates to ecosystem functioning: the allometric perspective. Naturwissenschaften 93, 467-479. doi: 10.1007/s00114-006-0130-1

Ostle, N., Briones, M. J. I., Ineson, P., Cole, L., Staddon, P., and Sleep, D. (2007) Isotopic detection of recent photosynthate carbon flow into grassland rhizosphere fauna. Soil Biol. Biochem. 39, 768-777. doi: 10.1016/j.soilbio.2006. 09.025

Paton, T. R., Humphreys, G. S., and Mitchell, P. B. (1995). Soils: A New Global View. New Haven, CT: Yale University Press.

Pawluk, S. (1987). Faunal micromorphological features in moder humus of some western Canadian soils. Geoderma 40, 3-16. doi: 10.1016/0016-7061(87) 90010-3

Persson, T. (1989). Role of soil animals in C and N mineralisation. Plant Soil 115, 241-245. doi: 10.1007/BF02202592

Persson, T., Bååth, E., Clarholm, M., Lundkvist, H., Söderström, B. E., and Sohlenius, B. (1980). "Trophic structure, biomass dynamics and carbon metabolism of soil organisms in a Scots pine forest," in Structure and Function of Northern Coniferous Forest: An Ecosystem Study, ed T. Persson (Stockholm: Ecological Bulletins, vol. 32), 419-459.

Petersen, H. (1975). Estimation of dry weight, fresh weight, and calorific content of various Collembolan species. Pedobiologia 15, 222-243.

Petersen, H., and Luxton, M. (1982). A comparative analysis of soil fauna populations and their role in decomposition processes. Oikos 39, 287-388. doi: $10.2307 / 3544689$

Pfisterer, A. B., Joshi, J., Schmid, B., and Fischer, M. (2004). Rapid decay of diversity-productivity relationships after invasion in experimental plant communities. Basic Appl. Ecol. 5, 5-14. doi: 10.1078/1439-1791-00215

Pfisterer, A. B., and Schmid, B. (2002). Diversity-dependent production can decrease the stability of ecosystem functioning. Nature 416, 84-86. doi: $10.1038 / 416084 a$ 
Polis, G. A. (1991). Complex trophic interactions in deserts: an empirical critique of food-web theory. Am. Nat. 138, 123-155. doi: 10.1086/285208

Ponsard, S., and Arditi, R. (2000). What can stable isotopes $\left(\delta^{15} \mathrm{~N}\right.$ and $\left.\delta^{13} \mathrm{C}\right)$ tell about the food web of soil macro-invertebrates? Ecology 81, 852-864. doi: 10.1890/0012-9658(2000)081[0852:WCSINA]2.0.CO;2

Porco, D., Bedos, A., Greenslade, P., Janion, C., Skarzynsky, D., Stevens, M. I., et al. (2012). Challenging species delimitation in Collembola: cryptic diversity among common springtails unveiled by DNA barcoding. Invertebr. Syst. 26, 470-477. doi: 10.1071/IS12026

Porco, D., Decaëns, T., Deharveng, L., James, S. W., Skarzynski, D., Erseus, C., et al. (2013). Biological invasions in soil: DNA barcoding as a monitoring tool in a multiple taxa survey targeting European earthworms and springtails in North America. Biol. Invasions 15, 899-910. doi: 10.1007/s10530-0120338-2

Power, M. E., and Mills, L. S. (1995). The keystone cops meet in Hilo. Trends Ecol. Evol. 10, 182-184. doi: 10.1016/S0169-5347(00)89047-3

Pratt, J. R., and Cairns, J. (1985). Functional groups in the Protozoa: roles in differing ecosystems. J. Protozool. 32, 415-423. doi: 10.1111/j.15507408.1985.tb04037.x

Richard, B. (2008). Evaluation de la Diversité Specifique des vers de Terre de Haute Normandie par L'utilisation des Codes Barres ADN. Master's thesis, Lyon: Université de Lyon.

Rigamonte, T. A., Pylro, V. S., and Duarte, G. F. (2010). The role of mycorrhization helper bacteria in the establishment and action of ectomycorrhizae associations. Braz. J. Microbiol. 41, 832-840. doi: 10.1590/S1517-83822010000400002

Roesner, J. (1986). Untersuchungen zur Reproduktion von Nematoden in Boden durch Regenwürmer. Mededelingen van den Faculteit Landbouwwetenschappen Rijkuniversteit Gent 51, 1311-1318.

Root, R. B. (1967). The niche exploitation pattern of the blue-gray gnatcatcher. Ecol. Monogr. 37, 317-350. doi: 10.2307/1942327

Root, R. B. (1973). Organization of a plant-arthropod association in simple and diverse habitats: the fauna of collards (Brassica oleracea). Ecol. Monogr. 43, 95-124. doi: 10.2307/1942161

Rougerie, R., Decaëns, T., Deharveng, L., Porco, D., James, S. W., Chang, C.-H., et al. (2009). DNA bar-codes for soil animal taxonomy: transcending the final frontier. Pesqui. Agropecu. Bras. 44, 789-801. doi: 10.1590/S0100204X2009000800002

Rückamp, D., Amelung, W., Theisz, N., Bandeira, A. G., and Martius, C. (2010). Phosphorous forms in Brazilian termite nests and soils: relevance of feeding guild and ecosystems. Geoderma 155, 269-279. doi: 10.1016/j.geoderma.2009.12.010

Ruess, L., Haggblom, M. M., Langel, R., and Scheu, S. (2004). Nitrogen isotope ratios and fatty acid composition as indicators of animal diets in belowground systems. Oecologia 139, 336-346. doi: 10.1007/s00442-004-1514-6

Rusek, J. (1998). Biodiversity of Collembola and their functional role in the ecosystem. Biodivers. Conserv. 7, 1207-1219. doi: 10.1023/A:1008887817883

Scheu, S., and Falca, M (2000). The soil food web of two beech forests (Fagus sylvatica) of contrasting humus type: stable isotope analysis of a macro- and a mesofauna-dominated community. Oecologia 123, 285-296. doi: $10.1007 / \mathrm{s} 004420051015$

Scheu, S., and Setälä, H. (2002). "Multitrophic interactions in decomposer food-webs," in Multitrophic Level Interactions, eds B. Tscharntke and B. A. Hawkins (Cambridge: Cambridge University Press), 223-264. doi: 10.1017/СВО9780511542190.010

Schneider, K., Migge, S., Norton, R. A., Scheu, S., Langel, R., Reineking, A., et al. (2004). Trophic niche differentiation in soil microarthropods (Oribatida: Acari): evidence from stable isotope ratios $\left({ }^{15} \mathrm{~N} /{ }^{14} \mathrm{~N}\right)$. Soil Biol. Biochem. 36, 1769-1774. doi: 10.1016/j.soilbio.2004.04.033

Schulz, E., and Scheu, S. (1994). Oribatid mite mediated changes in litter decomposition: model experiments with ${ }^{14} \mathrm{C}$-labelled holocellulose. Pedobiologia 38 , $344-352$.

Setälä, H. (1995). Growth of birch and pine seedlings in relation to grazing by soil fauna on ectomycorrhizal fungi. Ecology 76, 1844-1851. doi: 10.2307/1940716

Setälä, H. (2000). Reciprocal interactions between Scots pine and soil web structure in the presence and absence of ectomycorrhiza. Oecologia 125, 109-118. doi: 10.1007/PL00008881

Setälä, H., and Huhta, V. (1991). Soil fauna increase Betula pendula growth: laboratory experiments with coniferous forest floor. Ecology 72, 665-671. doi: $10.2307 / 2937206$
Setälä, H., Marshall, V. G., and Trofymow, J. A (1996). Influence of body size of soil fauna on litter decomposition and ${ }^{15} \mathrm{~N}$ uptake by poplar in a pot trial. Soil Biol. Biochem. 28, 1661-1675. doi: 10.1016/S0038-0717(96)00252-0

Siepel, H. (1994). Life-history tactics of soil microarthropods. Biol. Fertil. Soils 18, 263-278. doi: 10.1007/BF00570628

Siepel, H., and De Ruiter-Dijkman, E. M. (1993). Feeding guilds of oribatid mites based on their carbohydrase activities. Soil Biol. Biochem. 25, 1491-1497. doi: 10.1016/0038-0717(93)90004-U

Standen, V., and Latter, P. M. (1977). Distribution of a population of Cognettia sphagnetorum (Enchytraeidae) in relation to microhabitats in a blanket bog. J. Anim. Ecol. 46, 213-229. doi: 10.2307/3957

Stevens, M. H. H., and Carson, W. P. (2001). Phenological complementarity, species diversity and ecosystem functioning. Oikos 92, 291-296. doi: 10.1034/j.16000706.2001.920211.x

Stoll, P., and Prati, D. (2001). Intraspecific aggregation alters competitive interactions in experimental plant communities. Ecology 82, 319-327. doi: 10.1890/0012-9658(2001)082[0319:IAACII]2.0.CO;2

Swift, M. J., Heal, O. W., and Anderson, J. M. (1979). Decomposition in Terrestrial Ecosystems. Oxford: Blackwell Science.

Takeda, H. (1995). Changes in the collembolan community during the decomposition of needle litter in a coniferous forest. Pedobiologia 39, 304-317.

Tayasu, I., Hyodo, F., Abe, T., Inoue, T., and Spain, A. V. (2002). Nitrogen and carbon stable isotope ratios in the sympatric Australian termites, Amitermes laurensis and Drepanotermes rubriceps (Isoptera: Termitidae) in relation to their feeding habits and the quality of their food materials. Soil Biol. Biochem. 34, 297-301. doi: 10.1016/S0038-0717(01)00181-X

Torsvik, V., Goksoyr, J., Daae, F. L., Sorheim, R., Michalsen, J., and Salte, K. (1994). "Use of DNA analysis to determine the diversity of microbial communities," in Beyond the Biomass, eds K. Ritz, J. Dighton, and K. E. Giller (Chichester: John Wiley and Sons), 39-48.

Torsvik, V., and Øvreås, L. (2002). Microbial diversity and function in soil: from genes to ecosystems. Curr. Opin. Microbiol. 5, 240-245. doi: 10.1016/S13695274(02)00324-7

Uroz, S., Courty, P. E., Pierrat, J. C., Peter, M., Buee, M., Turpault, M. P., et al. (2013). Functional profiling and distribution of the forest soil bacterial communities along the soil mycorrhizosphere continuum. Microbiol. Ecol. 66, 404-441. doi: 10.1007/s00248-013-0199-y

Van der Drift, J. (1965). "The effects of animal activity in the litter layer," in Experimental Pedology, ed E. G. Hallsworth and D. V. Crawford (London: Butterworths), 227-235.

Verhoef, H. A., and Witteveen, J. (1980). Water balance in Collembola and its relation to habitat selection: cuticular water loss and water uptake. J. Insect Physiol. 26, 201-208. doi: 10.1016/0022-1910(80)90081-5

Vineesh, P. J., Sabu, T. K., and Karmaly, K. A. (2007). Community structure and functional group classification of litter ants in the montane evergreen and deciduous forests of Wayanad region of western Ghats, southern India. Orient. Insects 41, 427-442. doi: 10.1080/00305316.2007.10417526

Waid, J. (1999). Does soil biodiversity depend upon metabiotic activity and influences? Appl. Soil Ecol. 13, 151-158. doi: 10.1016/S0929-1393(99)00030-X

Wall, D. H., Bradford, M. A., John, M. G. S. T., Trofymow, J. A., Behan-Pelletier, V., Bignell, D. E., et al. (2008). Global decomposition experiment shows soil animal impacts on decomposition are climate-dependent. Glob. Change Biol. 14, 2661-2677.

Wallwork, J. A. (1970). Ecology of Soil Animals. London: McGraw-Hill.

Walter, D. E., Hunt, H. W., and Elliot, E. T. (1988). Guilds or functional groups? An analysis of predatory arthropods from a shortgrass steppe soil. Pedobiologia 31, 247-260.

Walter, D. E., and Proctor, H. C. (1999). Mites: Ecology, Evolution and Behaviour Sydney; New York, NY: University of New South Wales Press; CAB International.

Wardle, D. A. (2002). Communities and Ecosystems. Princeton, NJ: Princeton University Press.

Wardle, D. A., and Lavelle, P. (1996). "Linkages between soil biota, plant litter quality and decomposition," in Driven by Nature: Plant Litter Quality and Decomposition, eds G. Cadisch and K. E. Giller (Wallingford, WA: CAB International), 107-123.

Wolters, V. (2001). Biodiversity of soil animals and its function. Eur. J. Soil Biol. 37, 221-227. doi: 10.1016/S1164-5563(01)01088-3

Wood, T. G. (1988) Termites and the soil environment. Biol. Fert. Soils 6, 228-236. doi: $10.1007 / \mathrm{BF} 00260819$ 
Yachi, S., and Loreau, M. (1999). Biodiversity and ecosystem productivity in a fluctuating environment: the insurance hypothesis. Proc. Natl. Acad. Sci. U.S.A. 96, 1463-1468. doi: 10.1073/pnas.96. 4.1463

Yeates, G. W., Bongers, T., de Goede, R. G. M., Freckman, D. W., and Georgieva, S. S. (1993). Feeding habits in soil nematode families and genera-an outline for soil ecologists. J. Nematol. 25, 315-331.

Conflict of Interest Statement: The author declares that the research was conducted in the absence of any commercial or financial relationships that could be construed as a potential conflict of interest.
Received: 06 February 2014; accepted: 03 April 2014; published online: 22 April 2014. Citation: Briones MJI (2014) Soil fauna and soil functions: a jigsaw puzzle. Front. Environ. Sci. 2:7. doi: 10.3389/fenvs.2014.00007

This article was submitted to Soil Processes, a section of the journal Frontiers in Environmental Science.

Copyright (c) 2014 Briones. This is an open-access article distributed under the terms of the Creative Commons Attribution License (CC BY). The use, distribution or reproduction in other forums is permitted, provided the original author(s) or licensor are credited and that the original publication in this journal is cited, in accordance with accepted academic practice. No use, distribution or reproduction is permitted which does not comply with these terms. 